\title{
Protease-Activated Receptor 2 Sensitizes the Capsaicin Receptor Transient Receptor Potential Vanilloid Receptor 1 to Induce Hyperalgesia
}

\author{
Silvia Amadesi, ${ }^{1 \star}$ Jingjiang Nie, ${ }^{2 *}$ Nathalie Vergnolle, ${ }^{3 \star}$ Graeme S. Cottrell, ${ }^{1}$ Eileen F. Grady, ${ }^{1}$ Marcello Trevisani, ${ }^{4}$ \\ Chiara Manni, ${ }^{4}$ Pierangelo Geppetti, ${ }^{4}$ James A. McRoberts, ${ }^{2}$ Helena Ennes, ${ }^{2}$ John B. Davis, ${ }^{5}$ Emeran A. Mayer, ${ }^{2}$ and \\ Nigel W. Bunnett ${ }^{1}$ \\ ${ }^{1}$ Departments of Surgery and Physiology, University of California, San Francisco, California 94143-0660, ${ }^{2}$ Center for Neurovisceral Sciences and Women's \\ Health, University of California Los Angeles Division of Digestive Diseases, Los Angeles, California 90095, ${ }^{3}$ Department of Pharmacology and Therapeutics, \\ University of Calgary, Calgary, Alberta T2N 4N1, Canada, ${ }^{4}$ Department of Experimental and Clinical Medicine, University of Ferrara, 44100 Ferrara, Italy, \\ and ${ }^{5}$ GlaxoSmithKline Research and Development, Department of Neurology, Gastrointestinal Centres of Excellence for Drug Discovery, Harlow GM19 \\ $5 \mathrm{AW}$, United Kingdom
}

Inflammatory proteases (mast cell tryptase and trypsins) cleave protease-activated receptor $2\left(\mathrm{PAR}_{2}\right)$ on spinal afferent neurons and cause persistent inflammation and hyperalgesia by unknown mechanisms. We determined whether transient receptor potential vanilloid receptor 1 (TRPV1), a cation channel activated by capsaicin, protons, and noxious heat, mediates PAR $_{2}$-induced hyperalgesia. PAR $_{2}$ was coexpressed with TRPV1 in small- to medium-diameter neurons of the dorsal root ganglia (DRG), as determined by immunofluorescence. $\mathrm{PAR}_{2}$ agonists increased intracellular $\left[\mathrm{Ca}^{2+}\right]\left(\left[\mathrm{Ca}^{2+}\right]_{\mathrm{i}}\right)$ in these neurons in culture, and $\mathrm{PAR}_{2}$-responsive neurons also responded to the TRPV1 agonist capsaicin, confirming coexpression of $\mathrm{PAR}_{2}$ and TRPV1. $\mathrm{PAR}_{2}$ agonists potentiated capsaicin-induced increases in $\left[\mathrm{Ca}^{2+}\right]_{\mathrm{i}}$ in TRPV1-transfected human embryonic kidney (HEK) cells and DRG neurons and potentiated capsaicin-induced currents in DRG neurons. Inhibitors of phospholipase $\mathrm{C}$ and protein kinase $\mathrm{C}(\mathrm{PKC})$ suppressed $\mathrm{PAR}_{2}$-induced sensitization of TRPV1-mediated changes in $\left[\mathrm{Ca}^{2+}\right]_{\mathrm{i}}$ and TRPV1 currents. Activation of $\mathrm{PAR}_{2}$ or PKC induced phosphorylation of TRPV1 in HEK cells, suggesting a direct regulation of the channel. Intraplantar injection of a $\mathrm{PAR}_{2}$ agonist caused persistent thermal hyperalgesia that was prevented by antagonism or deletion of TRPV1. Coinjection of nonhyperalgesic doses of $\mathrm{PAR}_{2}$ agonist and capsaicin induced hyperalgesia that was inhibited by deletion of TRPV1 or antagonism of PKC. $\mathrm{PAR}_{2}$ activation also potentiated capsaicin-induced release of substance $\mathrm{P}$ and calcitonin gene-related peptide from superfused segments of the dorsal horn of the spinal cord, where they mediate hyperalgesia. We have identified a novel mechanism by which proteases that activate $\mathrm{PAR}_{2}$ sensitize TRPV1 through PKC. Antagonism of PAR 2 , TRPV1, or PKC may abrogate protease-induced thermal hyperalgesia.

Key words: protease-activated receptors; TRPV1; protein kinase C; hyperalgesia; inflammation; substance P

\section{Introduction}

Proteases from the circulation, inflammatory cells, epithelial cells, and neurons, which are generated during injury, cleave protease-activated receptors (PARs) to regulate hemostasis, inflammation, pain, and healing (Ossovskaya and Bunnett, 2004). Cleavage exposes tethered ligand domains that bind and activate cleaved receptors. Thrombin activates $\mathrm{PAR}_{1}, \mathrm{PAR}_{3}$, and $\mathrm{PAR}_{4}$ (Vu et al., 1991; Ishihara et al., 1997; Kahn et al., 1998), and factors VIIa and Xa activate $\mathrm{PAR}_{2}$ and $\mathrm{PAR}_{1}$ (Camerer et al.,

\footnotetext{
Received Dec. 23, 2003; revised Feb. 11, 2004; accepted March 18, 2004.

This work was supported by National Institutes of Health Grants DK57480 (N.W.B., E.A.M.), DK43207 (N.W.B.), and DK52388 (E.F.G.), a Robert Wood Johnson Focused giving award (N.W.B.), the Canadian Institutes of Health Research (N.V.), the Alberta Heritage Foundation of Medical Research (N.V.), and the Canadian Crohn's and Colitis Foundation (N.V.).

*S.A., J.N., and N.V. contributed equally to this work.

Correspondence should be addressed to Dr. Nigel W. Bunnett, University of California, 521 Parnassus Avenue, San Francisco, CA 94143-0660. E-mail: nigelb@itsa.ucsf.edu.

DOI:10.1523/JNEUROSCI.5679-03.2004

Copyright $\odot 2004$ Society for Neuroscience $\quad$ 0270-6474/04/244300-13\$15.00/0
}

2000). Mast cell tryptase activates $\mathrm{PAR}_{2}$ (Corvera et al., 1997; Molino et al., 1997), and neutrophil cathepsin G activates $\mathrm{PAR}_{4}$ (Sambrano et al., 2000). Pancreatic and extrapancreatic trypsins activate $\mathrm{PAR}_{2}$ and $\mathrm{PAR}_{4}$ (Nystedt et al., 1994; Kahn et al., 1998; Alm et al., 2000; Sawada et al., 2000; Cottrell et al., 2004).

Many of the effects of proteases that activate $\mathrm{PAR}_{2}$ are mediated by receptors in the peripheral nervous system. $\mathrm{PAR}_{2}$ is expressed by dorsal root ganglia (DRG) neurons containing substance P (SP) and calcitonin gene-related peptide (CGRP) (Steinhoff et al., 2000), which control inflammation and pain. $\mathrm{PAR}_{2}$ agonists stimulate SP and CGRP release from the peripheral projections of DRG neurons in the skin and intestine, causing edema and hyperemia ("neurogenic inflammation"; Steinhoff et al., 2000; Cenac et al., 2002, 2003). They also stimulate airway constriction (Ricciardolo et al., 2000) and gastric mucus secretion (Kawabata et al., 2001b) by neurogenic mechanisms. Intraplantar injection of $\mathrm{PAR}_{2}$ agonists induces neuropeptide release from the central projections of DRG neurons in the spinal cord to activate nociceptive neurons and cause hyperalgesia 
(Kawabata et al., 2001a; Vergnolle et al., 2001). Activation of $\mathrm{PAR}_{2}$ in the pancreas and intestine also excites nociceptive neurons and induces visceral hyperalgesia (Hoogerwerf et al., 2001; Coelho et al., 2002; Kirkup et al., 2003). However, the mechanisms by which $\mathrm{PAR}_{2}$ regulates neuronal function to cause inflammation and hyperalgesia are unknown.

We investigated the contribution of transient receptor potential vanilloid receptor 1 (TRPV1) to $\mathrm{PAR}_{2}$-mediated hyperalgesia. TRPV1 is a nonselective cation channel expressed by nociceptive neurons that makes a major contribution to inflammatory and thermal hyperalgesia (Caterina et al., 1997; Caterina et al., 2000; Davis et al., 2000). Exogenous (capsaicin and ethanol) and endogenous (protons of $\mathrm{pH}<6.0$, noxious heat of $>43^{\circ} \mathrm{C}$, and anandamide) factors directly activate TRPV1 (Caterina et al., 1997; Zygmunt et al., 1999; Trevisani et al., 2002). Inflammatory agents that activate G-protein-coupled receptors [e.g., bradykinin, ATP, and prostaglandin $\mathrm{E}_{2}\left(\mathrm{PGE}_{2}\right)$ (Tominaga et al., 2001; Vellani et al., 2001; Hu et al., 2002; Rathee et al., 2002; Mohapatra and Nau, 2003)] and receptor-tyrosine kinases (e.g., NGF; Shu and Mendell, 1999; Chuang et al., 2001) can indirectly sensitize TRPV1 to cause hyperalgesia.

We hypothesized that $\mathrm{PAR}_{2}$ sensitizes TRPV1 to induce hyperalgesia. Sensitization is suggested by the observations that $\mathrm{PAR}_{2}$ agonists enhance capsaicin-evoked CGRP release from DRG and fos expression in spinal neurons (Hoogerwerf et al., 2001). The TRPV1 antagonist capsazepine attenuates $\mathrm{PAR}_{2}$ stimulated thermal hyperalgesia (Kawao et al., 2002) and gastric mucus secretion (Kawabata et al., 2002). However, direct evidence of $\mathrm{PAR}_{2}$-induced sensitization of TRPV1 is lacking and the molecular mechanisms are unknown. Our aims were (1) to determine whether $\mathrm{PAR}_{2}$ activation sensitizes TRPV1 Ca ${ }^{2+}$ signaling and TRPV1 currents to induce thermal hyperalgesia; (2) to elucidate the mechanism of sensitization; (3) to determine whether $\mathrm{PAR}_{2}$ activation phosphorylates TRPV1; and (4) to investigate whether $\mathrm{PAR}_{2}$ activation potentiates TRPV1-induced release of neuropeptides from the central projections of nociceptive DRG neurons.

\section{Materials and Methods}

Animals. Sprague Dawley rats (male, 200-250 gm) and C57BL/6 mice (6-8 weeks) were from Charles River Laboratories. TRPV1 ${ }^{-1-}$ and TRPV1 ${ }^{+/+}(\mathrm{C} 57 \mathrm{BL} / 6 \mathrm{~J})$ mice were from The Jackson Laboratory (Bar Harbor, ME). Littermates were used in control experiments. Procedures were approved by Institutional Animal Care and Use Committees.

PAR activators and inhibitors. Synthetic peptides corresponding to the tethered ligands [activating peptides (APs)] can directly activate $\mathrm{PAR}_{1}, \mathrm{PAR}_{2}$, and $\mathrm{PAR}_{4}$ and are useful tools for investigating receptor functions. $\mathrm{PAR}_{2}$-AP (SLIGRL- $\mathrm{NH}_{2}$ ), corresponding to the tethered ligand of the rat receptor, and an analog of $\mathrm{PAR}_{1}$ - $\mathrm{AP}$ (TFLLR- $\mathrm{NH}_{2}$ ), which specifically activates $\mathrm{PAR}_{1}$, were synthesized and purified as described (Steinhoff et al., 2000). The reverse peptide sequences (PAR-RP), which do not activate PARs, were used for controls. Tryptase was purified from human lung (Steinhoff et al., 2000). Bovine pancreatic trypsin was from Worthington (Lakewood, NJ). Thrombin, U73122 [1-[6-((17b-3-methoxyestra-1,3,5(10)-trien-17yl)amino)hexyl]-1H-pyrrole-2,5-dione], GFX [(2-[1-(3-dimethyla minopropyl)-1H-indol-3-yl]-3-(1H-indol-3-yl)-maleimide], Gö6976 [12-(2-cyanoethyl)-6,7,12,13-tetrahydro-13-methyl-5-oxo$5 \mathrm{H}$-indolo(2,3-a)pyrrolo(3,4-c)-carbazole, and phorbol-12-myristate 13-acetate (PMA) were from Calbiochem (La Jolla, CA). We used concentrations of agonists and antagonists that we have previously shown to selectively activate $\mathrm{PAR}_{1}$ and $\mathrm{PAR}_{2}$ in neurons (Steinhoff et al., 2000; de Garavilla et al., 2001) and that effectively and selectively inhibit the targeted enzymes (Bohm et al., 1996).
Cell and neuronal culture. Human embryonic kidney 293 (HEK293) cells stably expressing human TRPV1 were generated and maintained in Eagle's MEM with Earle's BSS medium (MEM), 10\% fetal bovine serum, and geniticin (400 mg/l) (Hayes et al., 2000). DRG from thoracic and lumbar spinal cord of rats were minced in cold HBSS and incubated for $60-90 \mathrm{~min}$ at $37^{\circ} \mathrm{C}$ in DMEM containing (in $\mathrm{mg} / \mathrm{ml}$ ): 0.5 trypsin, 1 collagenase type IA, and 0.1 DNase type IV (Sigma, St. Louis, MO) (Steinhoff et al., 2000). Soybean trypsin inhibitor (Sigma) was added to neutralize trypsin. Neurons were pelleted, suspended in DMEM containing $10 \%$ fetal bovine serum, $10 \%$ horse serum, $100 \mathrm{U} / \mathrm{ml}$ penicillin, $0.1 \mathrm{mg} / \mathrm{ml}$ streptomycin, 2 mu glutamine, and $2.5 \mu \mathrm{g} / \mathrm{ml}$ DNase type IV, plated on glass coverslips coated with Matrigel (BD Biosciences, Bedford, MA), and cultured for 2-3 d.

Reverse transcription-PCR. Total RNA from HEK293-TRPV1 $(1 \mu \mathrm{g})$ was reverse-transcribed with oligo $(\mathrm{dT})_{15}$ and avian myeloblastosis virus reverse transcriptase (Promega, Madison, WI). PCR reactions used primers specific to the $\mathrm{C}$ terminus of human $\mathrm{PAR}_{2}$ (forward, $5^{\prime}$-ccctttgtatgtcgtgaagcagac- $3^{\prime}$; reverse, $5^{\prime}$-ttcctggagtgtttctttgaggtg- $3^{\prime}$ ) and human $\mathrm{PAR}_{1}$ (forward, 5' -agcaaaccatccaggtgc- $3^{\prime}$; reverse, $5^{\prime}$-tgttataactgctgggatcg$\left.3^{\prime}\right)$. Control reactions omitted reverse transcriptase. Products were separated by electrophoresis ( $2 \%$ agarose gel), detected using ethidium bromide, and sequenced.

Immunofluorescence. Rats were transcardially perfused with $4 \%$ paraformaldehyde in $100 \mathrm{~mm}$ PBS, pH 7.4. DRG were fixed overnight and embedded on optimal cutting temperature compound, and $14 \mu \mathrm{m} \mathrm{sec}-$ tions were prepared (Steinhoff et al., 2000). Cultured DRG were fixed with $4 \%$ paraformaldehyde for $20 \mathrm{~min}$ at $4^{\circ} \mathrm{C}$. Sections and cultures were incubated with the primary antibodies for $16 \mathrm{hr}$ at $4^{\circ} \mathrm{C}: \mathrm{PAR}_{2}$, rabbit antibody (Ab) $\mathrm{B} 5$ to the $\mathrm{N}$ terminus of rat $\mathrm{PAR}_{2}$ (Dr. M. Hollenberg, University of Calgary; Kong et al., 1997), 1:250-1:500; and TRPV1, guinea pig $\mathrm{Ab}$ to the $\mathrm{C}$ terminus of rat TRPV1 (Chemicon, Temecula, CA), 1:1000-1:20,000. Sections and cultures were incubated with antirabbit or anti-guinea pig IgG conjugated to Texas Red or FITC (Jackson ImmunoResearch, West Grove, PA). In the case of the sections, the TRPV1 signal was amplified using a tyramide signal amplification system (PerkinElmer Life Sciences, Boston, MA). Specimens were observed using a Zeiss (Thornwood, NY) Axiovert and an MRC 1000 laser scanning confocal microscope (Bio-Rad, Hercules, CA). In controls, primary antibodies were preincubated with $10 \mu \mathrm{m}$ peptides used for immunization for $48 \mathrm{hr}$ at $4^{\circ} \mathrm{C}$, which abolished staining.

Immunoprecipitation and Western blotting. HEK-TRPV1 cells were maintained overnight in MEM and $0.1 \%$ BSA, incubated with agonists for $10 \mathrm{~min}$ at $37^{\circ} \mathrm{C}$, and lysed with radioimmunoprecipitation assay buffer. Samples $(500 \mu \mathrm{l})$ were incubated with rabbit anti-human TRPV1 ( $1 \mu \mathrm{g} / \mathrm{ml}$, overnight, $4^{\circ} \mathrm{C}$; Chan et al., 2003). Protein A/G Plus (Santa Cruz Biotechnology, Santa Cruz, CA; $30 \mu \mathrm{l}$ ) was added and mixed for 2 hr at $4^{\circ} \mathrm{C}$. Beads were pelleted, suspended in $2 \times$ SDS loading buffer, and boiled for $5 \mathrm{~min}$, and the supernatant was fractionated by SDS-PAGE ( $8 \%$ gel). Proteins were transferred to polyvinylidene difluoride membranes (Millipore, Billerica, MA). Membranes were incubated with Ab to phosphoserine (Zymed, South San Francisco, CA; 1:1000 in PBS, 2\% BSA, and $0.1 \%$ Tween 20 , overnight, $4^{\circ} \mathrm{C}$ ) and then with goat anti-rabbit horseradish peroxidase (Jackson ImmunoResearch; 1:10,000, $1 \mathrm{hr}$, room temperature). Immunoreactive proteins were detected by enhanced chemiluminescence (Amersham Biosciences, Piscataway, NJ). To ensure equal loading, membranes were stripped in $62.5 \mathrm{~nm}$ Tris- $\mathrm{HCl}, \mathrm{pH} 6.8,2 \%$ SDS, and $100 \mathrm{~mm} 2$-mercaptoethanol and re-probed with anti-TRPV1 $\left(0.2 \mu \mathrm{g} / \mathrm{ml}\right.$, overnight, $\left.4^{\circ} \mathrm{C}\right)$.

Measurement of intracellular $\left[\mathrm{Ca}^{2+}\right]$. HEK293-TRPV1 cells and DRG neurons were incubated in HBSS, 0.1\% BSA, and 20 mM HEPES, pH 7.4, containing 2.5-5 $\mu \mathrm{M}$ fura-2 AM (Molecular Probes, Eugene, OR) for $30-45 \mathrm{~min}$ at $37^{\circ} \mathrm{C}$ (Steinhoff et al., 2000). Coverslips were mounted in an open chamber at $37^{\circ} \mathrm{C}$. Fluorescence of individual cells was measured at 340 and $380 \mathrm{~nm}$ excitation and $510 \mathrm{~nm}$ emission using a Zeiss Axiovert microscope, an intensified CCD video camera (Stanford Photonics, Stanford, CA), and a video microscopy acquisition program (Axon Instruments, Union City, CA). Test substances were directly added to the chamber (50 $\mu$ l injection). Each coverslip received only one treatment with $\mathrm{PAR}_{2}-\mathrm{AP}$ or $-\mathrm{RP}$ followed by capsaicin. $\mathrm{DRG}$ preparations were challenged with $\mathrm{KCl}(50 \mathrm{~mm})$ at the end of each experiment. In some 
experiments, cells were pretreated with inhibitors for $30 \mathrm{~min}$ at $37^{\circ} \mathrm{C}$ before the challenge with test compounds. The magnitude of responses to test agents was calculated as the increase above baseline. Results are expressed as the $340: 380 \mathrm{~nm}$ emission ratio, which is proportional to the intracellular $\left[\mathrm{Ca}^{2+}\right]\left(\left[\mathrm{Ca}^{2+}\right]_{\mathrm{i}}\right)$. The effects of the inhibitors on sensitization of TRPV1 were calculated as a ratio and are expressed as a percentage of the potentiation observed in positive controls (100\%) pretreated with $\mathrm{PAR}_{2}$ agonists or PMA. To determine the source of PAR-induced increases in $\left[\mathrm{Ca}^{2+}\right]_{\mathrm{i}}$, some experiments were completed in $\mathrm{Ca}^{2+}$-free buffer.

Electrophysiology. DRG neurons were placed in an open recording chamber and perfused with Ringer's solution (in mM: $140 \mathrm{NaCl}, 5 \mathrm{KCl}, 2 \mathrm{CaCl}_{2}, 1 \mathrm{MgCl}_{2}, 10$ HEPES, and 10 glucose, $\mathrm{pH} 7.4$ at $21^{\circ} \mathrm{C}$ ). Membrane currents and voltages were recorded from small- and medium-diameter neurons under the whole-cell configuration with an Axon Instruments 1D patch-clamp amplifier. Recording pipettes (outer diameter, $1.65 \pm$ $0.05 \mu \mathrm{m}$ ) had resistances of 2-4 $\mathrm{M} \Omega$ when filled with buffer (in mM: $140 \mathrm{KCl}, 5 \mathrm{MgCl}_{2}, 4$ $\mathrm{Na}_{2}$ ATP, $0.3 \mathrm{Na}_{3} \mathrm{GTP}, 2.5 \mathrm{CaCl}_{2}$, 5 EGTA, and 10 HEPES, pH 7.2). After establishing the whole-cell configuration, neurons were required to maintain a zero-current potential of less than $-45 \mathrm{mV}$ for $5 \mathrm{~min}$. Voltage changes evoked by the injection of current or application of $\mathrm{PAR}_{2}$ agonists (applied by fast perfusion for $3 \mathrm{~min}$ ) were filtered at $2 \mathrm{kHz}$ and sampled at $20 \mathrm{kHz}$ using pClamp 8 software (Axon Instruments). To assess excitability, the rheobase was measured by step increases of the amount of injected current ( $40 \mathrm{pA}$ for $200 \mathrm{msec}$ every 30 sec) under the current-clamp mode (Abdulla and Smith, 1997). Capsaicin-induced currents were recorded under the voltage-clamp mode when membrane potential was held at $-60 \mathrm{mV}$ (Nicol and Cui, 1994). Whole-cell currents evoked by capsaicin were filtered at $1 \mathrm{kHz}$ and sampled at $1 \mathrm{KHz}$. Capsaicin was administered by fast perfusion for $150 \mathrm{msec}$ to $1 \mathrm{sec}$, adjusted according to the amplitude of the current. $\mathrm{PAR}_{2}-\mathrm{AP}$, trypsin, $\mathrm{PAR}_{2}-\mathrm{RP}$, and inactivated trypsin were also applied by fast perfusion for 3 min. Because of limited quantities, tryptase was "puffed" into the neurons (Picospritzer II; General Valve, Fairfield, NJ). In some experiments, neurons were pretreated with inhibitors for $5 \mathrm{~min}$. Rheobase is expressed as a change from basal (normalized to a basal value of 1) and as a percent change from basal rheobase. Membrane potential is expressed as absolute values (millivolts). TRPV1 currents are expressed as absolute values (nanoamperes) or as fold change from basal.

Paw withdrawal latency. $\mathrm{PAR}_{2}-\mathrm{AP}, \mathrm{PAR}_{2}-\mathrm{RP}$ (in sterile $0.9 \%$ saline), and capsaicin (in $80 \%$ sterile saline, $10 \%$ ethanol, and $10 \%$ Tween 80 ) were administered by intraplantar injection in mice (final, $10 \mu \mathrm{l} / \mathrm{paw}$ ) under light halothane (5\%) anesthesia (Vergnolle et al., 2001). Capsazepine $(35 \mathrm{mg} / \mathrm{kg}$, s.c.) was administered 30 min before the intraplantar injections. The protein kinase C (PKC) inhibitor GFX ( $1 \mu \mathrm{g}$ in $5 \mu \mathrm{l}$ ) or vehicle (saline) was administered by intraplantar injection immediately after the intraplantar injection of distilled water $(2 \mu \mathrm{l})$ to osmotically shock cells. These animals received
PAR $_{2}$-AP (1 ng) and capsaicin $(1 \mu \mathrm{g}) 15$ min later (final, $\left.5 \mu \mathrm{l}\right)$. The latency of paw withdrawal to a radiant heat stimulus was measured before and after the intraplantar injections of test substances using a plantar test apparatus (Ugo Basile, Milan, Italy). Thermal hyperalgesia was defined as a decrease in the withdrawal latency compared with the basal measurement. The investigator was unaware of the genotype of the $\mathrm{TRPV}^{+/+}$and TRPV $1^{-/-}$mice before the experiments.

Neuropeptide release from the dorsal horn of the spinal cord. Slices $(0.4$ $\mathrm{mm}$ ) of the dorsal spinal cord of rats were superfused at $0.4 \mathrm{ml} / \mathrm{min}$ with Krebs' solution (in mm: $119 \mathrm{NaCl}, 25 \mathrm{NaHCO}_{3}, 1.2 \mathrm{KH}_{2} \mathrm{PO}_{4}, 1.5 \mathrm{MgSO}_{4}$,
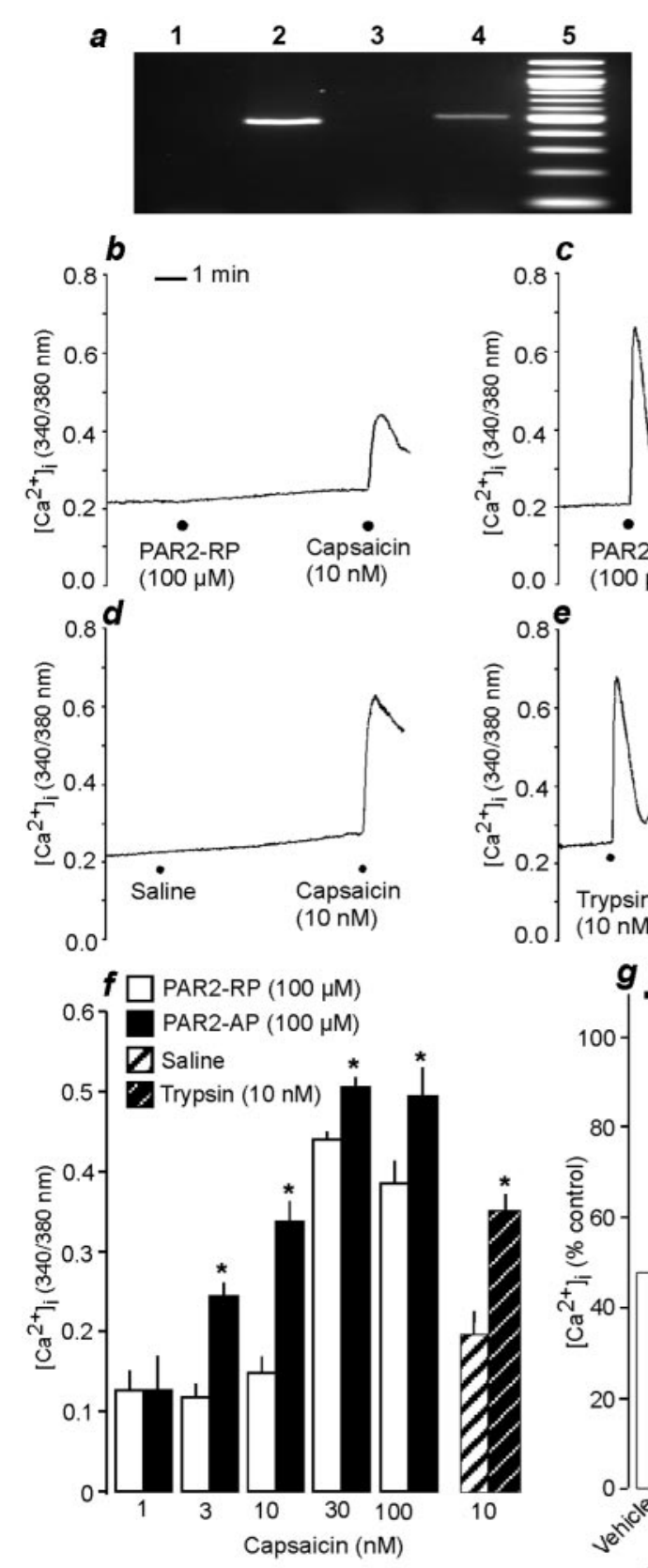

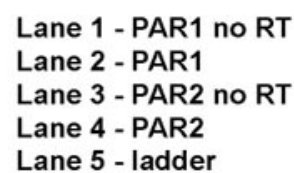

Lane 5 - ladder
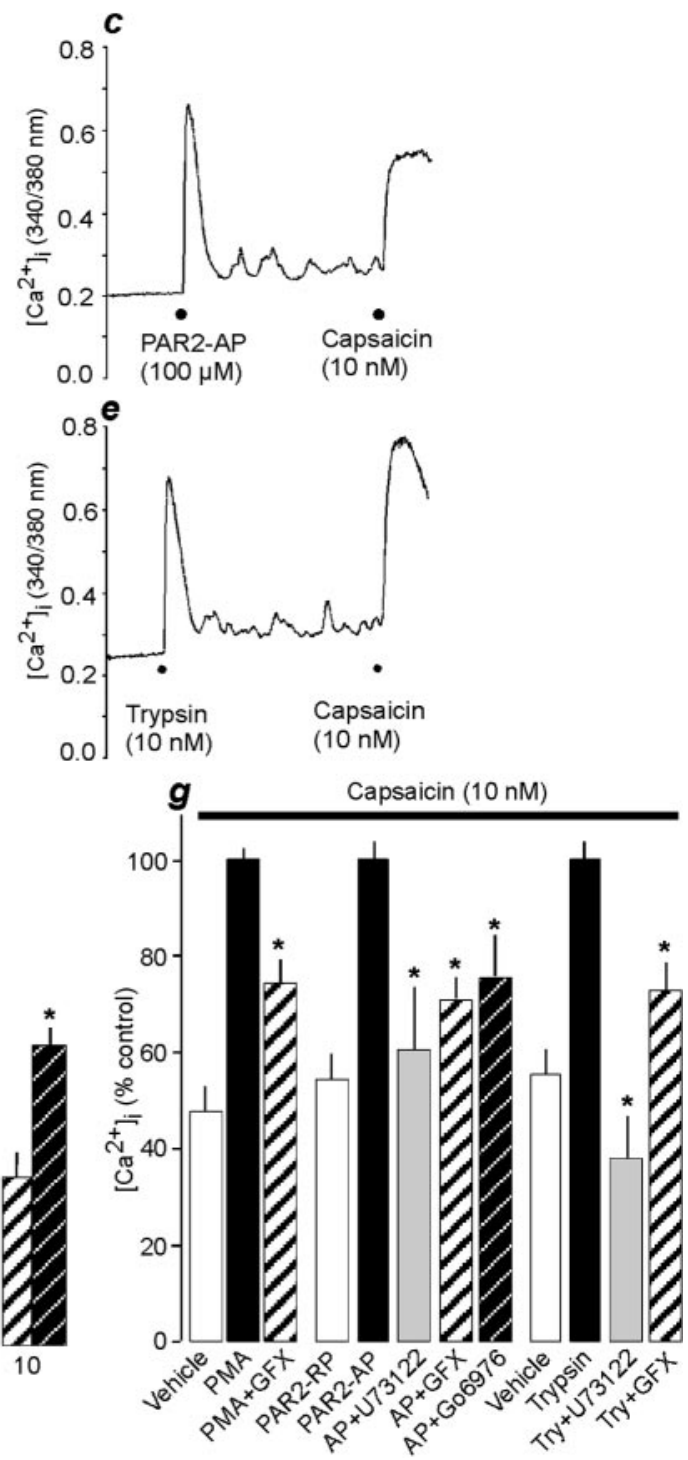

Figure 1. PAR activation sensitizes TRPV1 in transfected cells. a, HEK-TRPV1 cells express $P A R_{1}$ and PAR 2 . $m R N A$ for $P A R_{1}$ (lane 2) and PAR (lane 4) was detected in HEK-TRPV1 cells by RT-PCR. Lanes 1 and 3 are controls (no RT). Results are representative of three experiments. $b-g$, Cells were exposed to PAR - AP or -RP $(100 \mu \mathrm{M})$, trypsin $(10 \mathrm{nM})$, PMA $(5 \mu \mathrm{M})$, or vehicle for 5 min and were then challenged with capsaicin. $\operatorname{PAR}_{2}$ agonists $(c, e-g)$ and PMA $(g)$ potentiated responses to capsaicin. Inhibition of PLC (U73122, $5 \mu \mathrm{M}$ ) and PKC (GFX and Gö6976, 1 and $0.1 \mu \mathrm{M}$, respectively) suppressed the potentiation ( $g$ ). Results in $g$ are expressed as a percentage of the positive control (cells treated with $\operatorname{PAR}_{2}$ agonists or PMA). ${ }^{*} p<0.05$ compared with $\operatorname{PAR}_{2}-\operatorname{RP}$ or saline $(f)$, PMA, PAR $2-A P$, or trypsin $(g)$. Try, Trypsin; AP, PAR $-A P ; n=120-1040$ cells. 
$2.5 \mathrm{CaCl}_{2}, 4.7 \mathrm{KCl}$, and $11 \mathrm{D}$-glucose containing $0.1 \% \mathrm{BSA}, 1 \mu \mathrm{M}$ phosphoramidon, and $1 \mu \mathrm{M}$ captopril; $37^{\circ} \mathrm{C}, 95 \% \mathrm{O}_{2}$ and $5 \% \mathrm{CO}_{2}$ ). Slices were pretreated with $\mathrm{PAR}_{2}-\mathrm{AP}, \mathrm{PAR}_{2}-\mathrm{RP}$, or vehicle for $20 \mathrm{~min}$. The superfusate was then collected at $10 \mathrm{~min}$ intervals. After two basal collections, slices were perfused with capsaicin for $10 \mathrm{~min}$. Superfusate was analyzed for SP-like immunoreactivity (LI) and CGRP-LI by ELISA (Steinhoff et al., 2000). Peptide release was determined by subtracting basal levels from concentrations measured during and immediately after exposure to capsaicin. Results are expressed as femtomoles of peptide per gram of weighed tissue per $20 \mathrm{~min}$ period. The highest concentration of capsaicin, $\mathrm{PAR}_{2}-\mathrm{AP}$, and $\mathrm{PAR}_{2}-\mathrm{RP}$ did not interfere with the assays.

Statistical analysis. Results are expressed as mean \pm SEM and were compared by ANOVA and Student's $t$ test with Bonferroni correction or by Dunnett's test. Differences were considered significant at $p<0.05$.

\section{Results \\ $\mathrm{PAR}_{2}$ agonists sensitized TRPV1 $\mathrm{Ca}^{2+}$ responses in HEK- TRPV1 cells by activation of phospholipase $C$ and PKC}

We determined whether $\mathrm{PAR}_{2}$ activation sensitizes TRPV1 expressed in HEK293 cells. By using reverse transcription (RT)$\mathrm{PCR}$, we found that these cells endogenously expressed $\mathrm{PAR}_{2}$ mRNA (Fig. 1a). We measured $\left[\mathrm{Ca}^{2+}\right]_{\mathrm{i}}$ to assess activation of $\mathrm{PAR}_{2}$, which couples to mobilization of $\mathrm{Ca}^{2+}$, and TRPV1, a nonselective cation channel with preference for $\mathrm{Ca}^{2+}$ ions. $\mathrm{PAR}_{2}$-AP $(100 \mu \mathrm{M})$ and trypsin $(10 \mathrm{nM})$ rapidly increased $\left[\mathrm{Ca}^{2+}\right]_{\mathrm{i}}$, confirming expression of functional PAR 2 (Fig. 1c,e). This rapid increase in $\left[\mathrm{Ca}^{2+}\right]_{\mathrm{i}}$ was fully maintained in $\mathrm{Ca}^{2+}$-free medium and is thus attributable to mobilization of intracellular $\mathrm{Ca}^{2+}$ (data not shown). $\mathrm{PAR}_{2}-\mathrm{RP}$, which does not activate $\mathrm{PAR}_{2}$, had no effect on $\left[\mathrm{Ca}^{2+}\right]_{\mathrm{i}}\left(\right.$ Fig. 1 b). Exposure to $\mathrm{PAR}_{2}$-AP or trypsin potentiated $\mathrm{Ca}^{2+}$ responses to the selective TRPV1 agonist capsaicin applied 5 min later (1-100 nм; Fig. $1 b-f)$. The response to $10 \mathrm{nM}$ capsaicin was increased $127 \pm 12 \%$ by $\mathrm{PAR}_{2}-\mathrm{AP}(100$ $\mu \mathrm{M})$ and $79 \pm 10 \%$ by trypsin $(10 \mathrm{nM})$, compared with cells treated with $\mathrm{PAR}_{2}-\mathrm{RP}$ or vehicle. $\mathrm{PAR}_{2}-\mathrm{AP}$ increased both the potency and the efficacy of the response to capsaicin (Fig. 1f). Thus, $\mathrm{PAR}_{2}$ activation sensitizes TRPV1. Conversely, pretreatment with capsaicin (10 nM) did not affect the increase in $\left[\mathrm{Ca}^{2+}\right]_{\mathrm{i}}$ to $\mathrm{PAR}_{2}-\mathrm{AP}$ applied $5 \mathrm{~min}$ later $(10-100 \mu \mathrm{M}$; data not shown), indicating that TRPV1 activation does not sensitize $\mathrm{PAR}_{2}$.

The membrane phospholipid phosphatidylinositol-4,5bisphosphate ( $\mathrm{PIP}_{2}$ ) and phospholipase $\mathrm{C} \beta(\mathrm{PLC} \beta)$, which catalyzes the hydrolysis of $\mathrm{PIP}_{2}$ to 1,4,5-inositol trisphosphate $\left(\operatorname{InsP}_{3}\right)$ and diacylglycerol (DAG), regulate TRPV1 (Chuang et al., 2001; Prescott and Julius, 2003). We investigated whether $\mathrm{PAR}_{2}-$ induced potentiation of TRPV1 was mediated by PLC. Pretreatment with the PLC inhibitor U73122 (5 $\mu \mathrm{M}, 30 \mathrm{~min})$ attenuated the magnitude of the response to capsaicin ( $10 \mathrm{~nm}$ ) by $31 \pm 4 \%$ when compared with cells treated with vehicle (data not shown). These results are consistent with the observation that the inhibitory action of $\mathrm{PIP}_{2}$ on TRPV1 is enhanced by suppression of tonic PLC activity (Chuang et al., 2001; Hu et al., 2002; Prescott and Julius, 2003). Nonetheless, inhibition of PLC suppressed the potentiation of capsaicin responses induced by $\mathrm{PAR}_{2}$-AP by $>80 \%$ and eliminated potentiation by trypsin, reducing the response below levels in vehicle-treated cells. Thus, when compared with the positive control (capsaicin response in cells treated with $\mathrm{PAR}_{2}-\mathrm{AP}$ or trypsin, $100 \%$ ), the response to capsaicin was $61 \pm$ $13 \%$ after $\mathrm{U} 73122$ and $\mathrm{PAR}_{2}-\mathrm{AP}$ and $38 \pm 9 \%$ after U73122 and trypsin (Fig. 1g).

DAG generated by PLC $\beta$ from membrane phospholipids activates PKC. Because PKC can directly phosphorylate TRPV1 and thereby sensitize responses to TRPV1 agonists (Premkumar and Ahern, 2000; Vellani et al., 2001; Crandall et al., 2002; Numazaki et al., 2002), we hypothesized that PKC mediates $\mathrm{PAR}_{2}$-induced sensitization of TRPV1. The PKC activator PMA ( $5 \mu \mathrm{M}, 5 \mathrm{~min}$ ) enhanced the response to $10 \mathrm{~nm}$ capsaicin (Fig. $1 g$ ). This effect was reduced by $\sim 50 \%$ by the general PKC inhibitor GFX $(1 \mu \mathrm{M}$, $30 \mathrm{~min}$ ). Similarly, GFX inhibited $\mathrm{PAR}_{2}$-induced potentiation of responses to capsaicin $>60 \%$. The effects of capsaicin after GFX and $\mathrm{PAR}_{2}-\mathrm{AP}$ and GFX and trypsin were $71 \pm 5 \%$ and $73 \pm 6 \%$, respectively, when compared with the positive control (Fig. $1 g$ ). To characterize the isozymes of $\mathrm{PKC}$ that mediate $\mathrm{PAR}_{2}$-induced sensitization of TRPV1, we used Gö6976, an inhibitor of conventional PKC isoforms $\left(\alpha, \beta_{1}, \beta_{2}\right.$, and $\left.\gamma\right)$ but not the PKC $\epsilon$ isoform. Pretreatment with Gö6976 $(0.1 \mu \mathrm{M}, 30 \mathrm{~min})$ inhibited $\mathrm{PAR}_{2}-$ induced sensitization of responses to $10 \mathrm{~nm}$ capsaicin by $\sim 50 \%$. The effect of capsaicin after Gö6976 and $\mathrm{PAR}_{2}$-AP was $77 \pm 7 \%$ of the positive control (Fig. 1g). Pretreatment with GFX or Gö6976 did not affect the responses of capsaicin in cells treated with vehicle and $\mathrm{PAR}_{2}-\mathrm{RP}$ (data not shown).

\section{PAR $_{2}$ agonists sensitized TRPV1 $\mathrm{Ca}^{2+}$ responses in DRG neurons by activation of PLC and PKC}

To determine whether $\mathrm{PAR}_{2}$ and TRPV1 are coexpressed in DRG neurons, we localized the proteins by immunofluorescence in tissue sections and cultures and measured $\left[\mathrm{Ca}^{2+}\right]_{\mathrm{i}}$ in DRG cultures to selective agonists. Immunoreactive $\mathrm{PAR}_{2}$ and TRPV1 were colocalized in small- and medium-diameter $(\leq 30 \mu \mathrm{m})$ neurons in sections of DRG from adult rat (Fig. $2 a$, top panels), and expression was retained in culture (Fig. $2 a$, bottom panels). Capsaicin $(100 \mathrm{nM})$ increased $\left[\mathrm{Ca}^{2+}\right]_{\mathrm{i}}$ in $52 \pm 5 \%$ of neurons responding to $\mathrm{KCl}$ (50 mM; $n=103$ total neurons). $\mathrm{PAR}_{2}-\mathrm{AP}$ (100 $\mu \mathrm{M})$ increased $\left[\mathrm{Ca}^{2+}\right]_{\mathrm{i}}$ in $32 \pm 2 \%(n=439)$ of neurons, and trypsin $(10 \mathrm{nM})$ increased it in $44 \pm 9 \%(n=34)$ of neurons, whereas $\mathrm{PAR}_{2}-\mathrm{RP}$ was ineffective (Fig. $2 b-e$ ). We have previously shown that tryptase mobilizes $\mathrm{Ca}^{2+}$ in a similar proportion of neurons by activating $\mathrm{PAR}_{2}$ (Steinhoff et al., 2000). The rapid increase in $\left[\mathrm{Ca}^{2+}\right]_{i}$ was fully maintained in $\mathrm{Ca}^{2+}$-free medium and is thus attributable to mobilization of intracellular $\mathrm{Ca}^{2+}$ (data not shown). Most of the neurons responding to $\mathrm{PAR}_{2}-\mathrm{AP}$ (79 $\pm 3 \%)$ and all of the neurons responding to trypsin were capsaicin-sensitive (Fig. $2 d, e$ ). Thus, $\mathrm{PAR}_{2}$ and TRPV1 are mostly coexpressed in DRG neurons.

We examined whether $\mathrm{PAR}_{2}$ activation sensitizes TRPV1mediated increases in $\left[\mathrm{Ca}^{2+}\right]_{\mathrm{i}}$ in neurons. Exposure to $\mathrm{PAR}_{2}-\mathrm{AP}$ $(100 \mu \mathrm{M})$ and trypsin $(10 \mathrm{nM})$ potentiated the response to capsaicin (100 nM) applied 5 min later by $53 \pm 7 \%(n=231$ capsaicinresponsive neurons) and $88 \pm 24 \%(n=21)$, respectively, compared with control cells pretreated with $\mathrm{PAR}_{2}-\mathrm{RP}(100 \mu \mathrm{M} ; n=$ 140 ) or vehicle (PBS, 1:100; $n=17$; Fig. $2 b-g$ ). $\mathrm{PAR}_{2}$ activation also increased the proportion of neurons responding to capsaicin (Fig. $2 h$ ). After pretreatment with $\mathrm{PAR}_{2}-\mathrm{RP}$ and vehicle, $46 \pm 3 \%$ ( $n=304$ total neurons) and $53 \pm 9 \%(n=32)$, respectively, of neurons were capsaicin-sensitive. However, after pretreatment with $\mathrm{PAR}_{2}-\mathrm{AP}$ and trypsin, $65 \pm 3 \%(n=357)$ and $62 \pm 8 \%(n=$ 34 ), respectively, of neurons responded to capsaicin. Pretreatment with capsaicin $(10 \mathrm{nM})$ did not affect the response to $\mathrm{PAR}_{2}$-AP applied 5 min later (10-100 $\mu \mathrm{M}$; data not shown). Thus, $\mathrm{PAR}_{2}$ activation potentiates the magnitude of responses to capsaicin and increases the proportion of capsaicin-responsive neurons, indicating sensitization of TRPV1.

Inhibition of PLC with U73122 (5 $\mu \mathrm{M}, 30 \mathrm{~min})$ had no effect on the magnitude of the $\mathrm{Ca}^{2+}$ response to capsaicin (100 nM) but inhibited the $\mathrm{PAR}_{2}-\mathrm{AP}$-induced potentiation of the response to capsaicin by $>90 \%$; the effect of capsaicin after U73122 and $\mathrm{PAR}_{2}-\mathrm{AP}$ was $65 \pm 6 \%$ compared with the positive control of 
vehicle and $\mathrm{PAR}_{2}-\mathrm{AP}(100 \% ; n=72$ total neurons; Fig. $2 g$ ). Activation of PKC with PMA $(5 \mu \mathrm{M})$ potentiated the increase in $\left[\mathrm{Ca}^{2+}\right]_{\mathrm{i}}$ to capsaicin $(n=45)$ compared with cells pretreated with the vehicle $(n=$ $35)$. This effect was abolished by GFX (1 $\mu \mathrm{M}, 30 \mathrm{~min} ; n=22$; Fig. $2 g$ ). GFX also inhibited $\mathrm{PAR}_{2}-\mathrm{AP}$-induced potentiation of the response to capsaicin by $>80 \%$; the effect of capsaicin after GFX and $\mathrm{PAR}_{2}$-AP was $73 \pm 7 \%$ compared with the positive control ( $n=60$; Fig. $2 g$ ). Pretreatment with Gö6976 (0.1 $\mu \mathrm{M}, 30 \mathrm{~min})$ inhibited $\mathrm{PAR}_{2}$-induced sensitization of the response to capsaicin by $>80 \%$; the effect of capsaicin after Gö6976 and $\mathrm{PAR}_{2}-\mathrm{AP}$ was $73 \pm 16 \%$ compared with the positive control ( $n=37$; Fig. $2 g$ ).

Thus, observations in both HEKTRPV1 cells and DRG neurons indicate that $\mathrm{PAR}_{2}$ agonists sensitize TRPV1 by a mechanism that is dependent on PLC and the conventional isoforms of PKC.

\section{PAR $_{1}$ agonists did not sensitize TRPV1 $\mathrm{Ca}^{2+}$ responses in HEK-TRPV1 or DRG neurons}

To evaluate the specificity of $\mathrm{PAR}_{2}$ mediated sensitization of TRPV1, we investigated whether agonists of $\mathrm{PAR}_{1}$ sensitize this channel. $\mathrm{PAR}_{1}$ was endogenously expressed in HEK-TRPV1 cells (Fig. 1a) and is also present in smalldiameter DRG neurons (de Garavilla et al., 2001). $\mathrm{PAR}_{1}$-AP $(100 \mu \mathrm{M})$ rapidly increased $\left[\mathrm{Ca}^{2+}\right]_{\mathrm{i}}$ in HEK-TRPV1 cells (Fig. $3 b$ ) and DRG neurons (Fig. 3d), whereas $\mathrm{PAR}_{1}-\mathrm{RP}$ was ineffective. $\mathrm{PAR}_{1}-\mathrm{AP}$ increased $\left[\mathrm{Ca}^{2+}\right]_{\mathrm{i}}$ in $56 \pm 5 \%$ of DRG neurons $(n=117$ total neurons), $54 \pm 6 \%$ of which also responded to capsaicin. The rapid increase in $\left[\mathrm{Ca}^{2+}\right]_{\mathrm{i}}$ in HEK-TRPV1 cells and DRG neurons was still observed in $\mathrm{Ca}^{2+}$-free medium and is thus attributable to mobilization of intracellular $\mathrm{Ca}^{2+}$ (data not shown). $\mathrm{PAR}_{1}$-AP did not affect the magnitude of the $\mathrm{Ca}^{2+}$ response to 3 or $10 \mathrm{~nm}$ capsaicin in HEKTRPV1 cells (Fig. 3e) or to $100 \mathrm{~nm}$ capsaicin in DRG neurons ( $n=53$ capsaicinresponsive neurons; Fig. $3 f$ ). $\mathrm{PAR}_{1}$-AP also did not influence the number of capsaicinresponsive neurons (Fig, $3 g$ ). Thus, activation of $\mathrm{PAR}_{2}$ selectively sensitizes TRPV1.

\section{$\mathrm{PAR}_{2}$ agonists increased excitability of} DRG neurons

Activation of $\mathrm{PAR}_{2}$ on enteric neurons results in depolarization and sustained hyperexcitability (Linden et al., 2001; Gao et al., 2002; Reed et al., 2003). We therefore determined whether $\mathrm{PAR}_{2}$ activation depolarized small- and medium-diameter DRG neurons in culture and lowered their firing threshold, thereby increasing their excitability to other stimuli, by measuring the
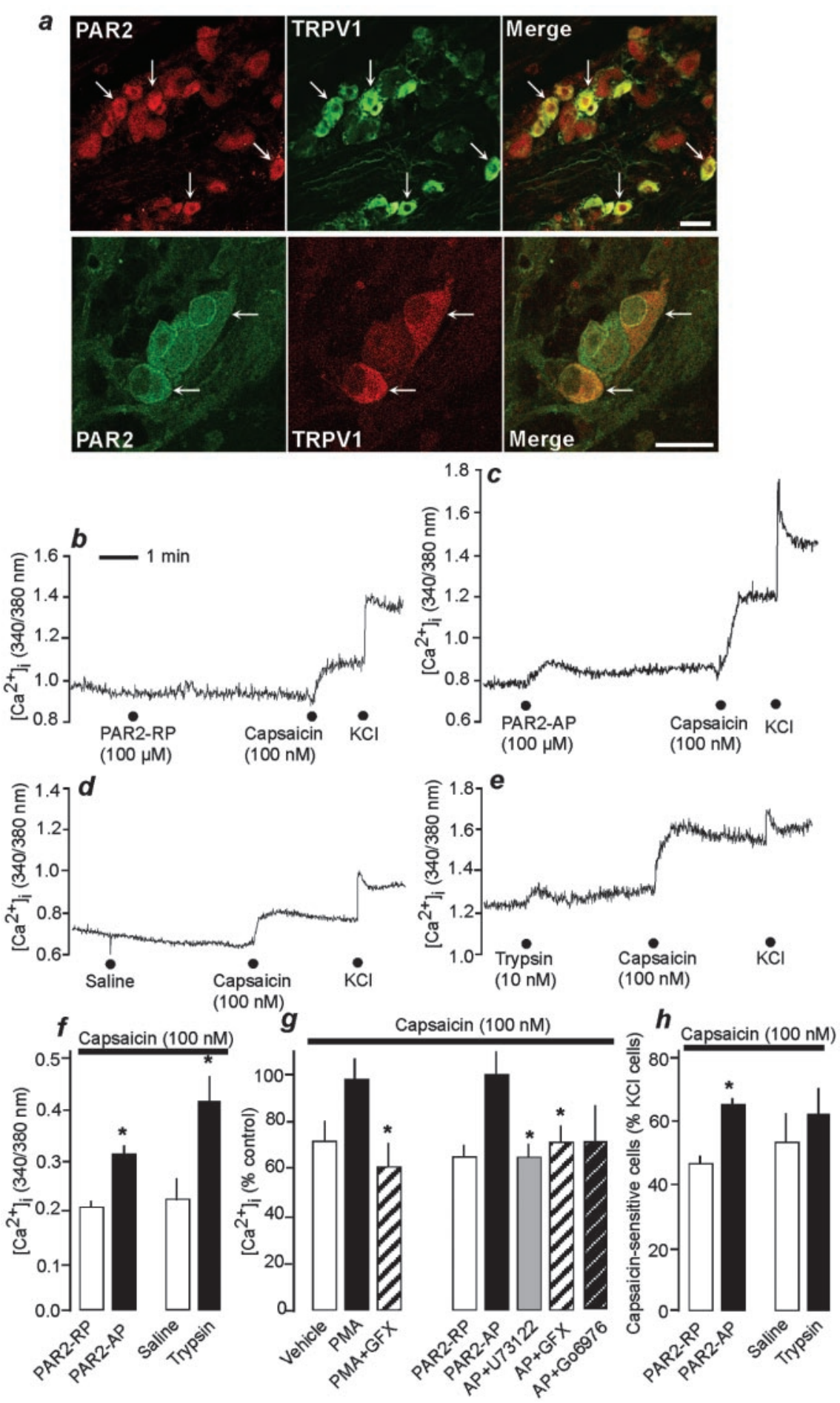

Figure 2. PAR activation sensitizes TRPV1 in DRG neurons. $a$, Colocalization (arrows) of immunoreactive PAR 2 and TRPV1 in tissue sections of DRG neurons (top panels) and in cultured DRG neurons (bottom panels). Scale bars: top panels, $50 \mu \mathrm{m}$; bottom panels, $25 \mu \mathrm{m} . b-h$, Neurons were exposed to PAR - AP or -RP (100 $\mu \mathrm{M})$, trypsin (10 nM), PMA $(5 \mu \mathrm{M})$ or vehicle for $5 \mathrm{~min}$, and were then challenged with capsaicin ( $100 \mathrm{nM})$. PAR $_{2}$ agonists $(c, e-h)$ and PMA $(g)$ potentiated responses to capsaicin. Inhibition of PLC (U73122, $5 \mu \mathrm{M})$ and PKC (GFX and Gö6976, 1 and $0.1 \mu \mathrm{m}$, respectively) suppressed the potentiation ( $g$ ). PAR activation also increased the proportion of neurons that gave detectable responses to capsaicin ( $h$ ). Results in $g$ are expressed as a percentage of the positive control (magnitude of capsaicin response in cells after $\mathrm{PAR}_{2}$ activation). ${ }^{*} p<0.05$ compared with $\mathrm{PAR}_{2}-\mathrm{RP}$ or saline $(f, h)$ and $\operatorname{PMA}$ or $\operatorname{PAR}_{2}-\operatorname{AP}(g)$. AP, $\operatorname{PAR}_{2}-\mathrm{AP} ; n=17-231$ neurons.

rheobase (minimum current to evoke one action potential in the current-clamp mode). The average initial rheobase was $0.83 \pm$ $0.11 \mathrm{nA}$ and was not statistically different between any of the experimental groups of neurons. Trypsin (10 nM, $3 \mathrm{~min})$ and 

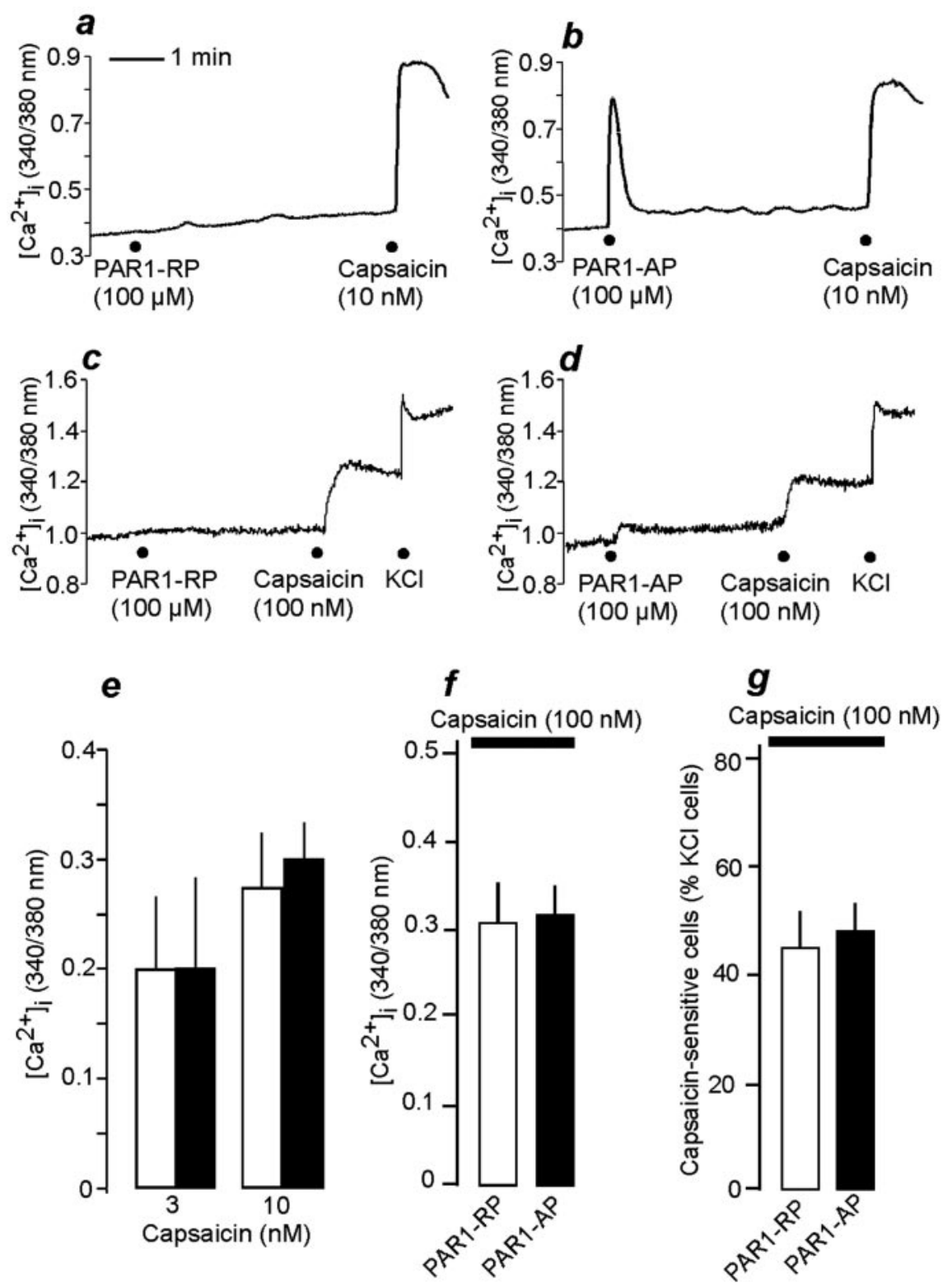

Figure 3. PAR activation does not sensitize TRPV1 in transfected cells $(a, b, e)$ or DRG neurons $(c, d, f, g)$. HEK-TRPV1 cells $(a, b$, $e)$ or DRG neurons $(c, d, f, g)$ were exposed to PAR $-A P$ or - RP $(100 \mu \mathrm{m})$ for $5 \mathrm{~min}$ and were then challenged with capsaicin. In HEK-TRPV1 cells, PAR $-A P$ failed to potentiate the response to 3 or $10 \mathrm{~nm}$ capsaicin $(b, e)$. In DRG, PAR $-A P$ failed to potentiate the magnitude of the response to $100 \mathrm{~nm}$ capsaicin $(d, f)$ or affect the proportion of neurons that gave a detectable response to capsaicin $(g) ; n=160-320$ cells, $28-53$ neurons.

tryptase $(3.8 \mu \mathrm{M}$ pipette concentration, puffed onto cells) induced a sustained decrease in the rheobase that was detected at 10 min and maintained for at least $50 \mathrm{~min}$ (50 min: trypsin, $59.6 \pm$ 9.6\% decrease; $n=7$ total neurons; tryptase, $50.4 \pm 3.5 \%$ decrease; $n=5$; Fig. $4 a, b$ ). Inactivated trypsin [ $10 \mathrm{nM}, 3 \mathrm{~min}$, pretreated with soybean trypsin inhibitor (SBTI), $10 \mathrm{mg} / \mathrm{ml}, 30 \mathrm{~min}$, $37^{\circ} \mathrm{C}$ ] had no effect on the rheobase (Fig. 4b). Surprisingly, $\mathrm{PAR}_{2}$-AP ( $50 \mu \mathrm{M}, 3 \mathrm{~min}$ ) increased rheobase at $10 \mathrm{~min}$ by $31 \%$ (Fig. 4a). However, $\mathrm{PAR}_{2}$-RP (50 $\mu \mathrm{M}, 3 \mathrm{~min}$ ) also increased the rheobase at this time to a similar extent (44\%), suggesting that the increase in rheobase to $\mathrm{PAR}_{2}-\mathrm{AP}$ is nonspecific. At later time points, $\mathrm{PAR}_{2}-\mathrm{AP}$ caused a sustained decrease in rheobase $(50$ min: $40.2 \pm 5.9 \% ; n=7$ ), whereas $\mathrm{PAR}_{2}-\mathrm{RP}$ had no effect (Fig. $4 a, b)$. The resting potential of neurons was $57.2 \pm 1.6 \mathrm{mV}$. Trypsin, tryptase, and $\mathrm{PAR}_{2}-\mathrm{AP}$ depolarized neurons after $10 \mathrm{~min}$ (trypsin, $11.0 \pm 2.1 \mathrm{mV} ; n=7$; tryptase, $13.2 \pm 2.5 \mathrm{mV} ; n=5 ; \mathrm{PAR}_{2}-\mathrm{AP}, 4.9 \pm 2.3$ $\mathrm{mV} ; n=7)$, but within $20 \mathrm{~min}$, the membrane potential had repolarized (Fig. $4 c, d)$. Inactivated trypsin and $\mathrm{PAR}_{2}-\mathrm{RP}$ had no effect on membrane potential (Fig. 4d). Thus, brief activation of $\mathrm{PAR}_{2}$ induces a sustained hyperexcitability of DRG neurons.

\section{$\mathrm{PAR}_{2}$ agonists sensitized TRPV1 currents in DRG neurons by activating $\mathrm{PKC}$}

To study the effect of activation of $\mathrm{PAR}_{2}$ on the activity of TRPV1, we measured whole-cell currents induced by capsaicin before and after $\mathrm{PAR}_{2}$ activation in DRG neurons. Approximately $50 \%$ of small and medium DRG neurons responded to brief (150 msec-1 sec) application of capsaicin (500 nM). Stable inward currents to repeated application (3 min interstimulus interval) of capsaicin were recorded in $40-50 \%$ of responsive neurons, whereas capsaicin currents desensitized in other neurons. Only neurons that did not exhibit desensitization to two consecutive capsaicin applications were selected for further study. $\mathrm{PAR}_{2}-\mathrm{AP}(50 \mu \mathrm{M}, 3 \mathrm{~min})$ and trypsin (10 $\mathrm{nM}, 3 \mathrm{~min})$ increased the inward current induced by capsaicin ( 500 nM; Fig. $5 a-c$ ). This potentiation was observed within $10 \mathrm{~min}$ of $\mathrm{PAR}_{2}$ activation and was sustained for at least $60 \mathrm{~min}$. For example, at $30 \mathrm{~min}$ after application of $\mathrm{PAR}_{2}-\mathrm{AP}$ or trypsin, the capsaicininduced TRPV1 current was significantly increased by a 3.1- \pm 0.6 -fold change over basal ( $n=6$ neurons) and 2.0- \pm 0.1 -fold $(n=10)$, respectively, compared with controls treated with $\mathrm{PAR}_{2}-\mathrm{RP}(50 \mu \mathrm{M}, 3$ min) or vehicle (Fig. $5 a-c$ ). The PKC inhibitor GFX ( $1 \mu \mathrm{M}, 5 \mathrm{~min})$ abolished the potentiation of the TRPV1 current induced by $\mathrm{PAR}_{2}$-AP $(1.1- \pm 0.2$-fold after GFX and $\mathrm{PAR}_{2}-\mathrm{AP} ; n=4$; compared with 4.5- \pm 1.2 -fold after vehicle and $\mathrm{PAR}_{2}$-AP;

Fig. $6 a, b)$. However, GFX had minimal affect on the basal TRPV1 current (Fig. $6 c, d$ ). Thus, transient activation of $\mathrm{PAR}_{2}$ causes sustained sensitization of TRPV1 by a $\mathrm{PKC}$-dependent process. In contrast, $\mathrm{PAR}_{1}-\mathrm{AP}(50 \mu \mathrm{M}, 3 \mathrm{~min})$ did not sensitize the capsaicin current (data not shown).

\section{PAR $_{2}$ agonists induced phosphorylation of TRPV1 in HEK-TRPV1 cells}

PKC can directly phosphorylate TRPV1 and thereby sensitize responses to TRPV1 agonists (Numazaki et al., 2002). Because $\mathrm{PAR}_{2}$-induced sensitization of TRPV1 requires PKC activation, we hypothesized that $\mathrm{PAR}_{2}$ activation can modify phosphorylation of TRPV1. To assess phosphorylation of TRPV1, we immunoprecipitated the channel and probed Western blots for phosphoserine. $\mathrm{PAR}_{2}$-AP (100 $\mu \mathrm{M}, 10 \mathrm{~min}$; Fig. 7) or trypsin (10 nM, $10 \mathrm{~min}$; data not shown) induced phosphorylation of TRPV1 in 

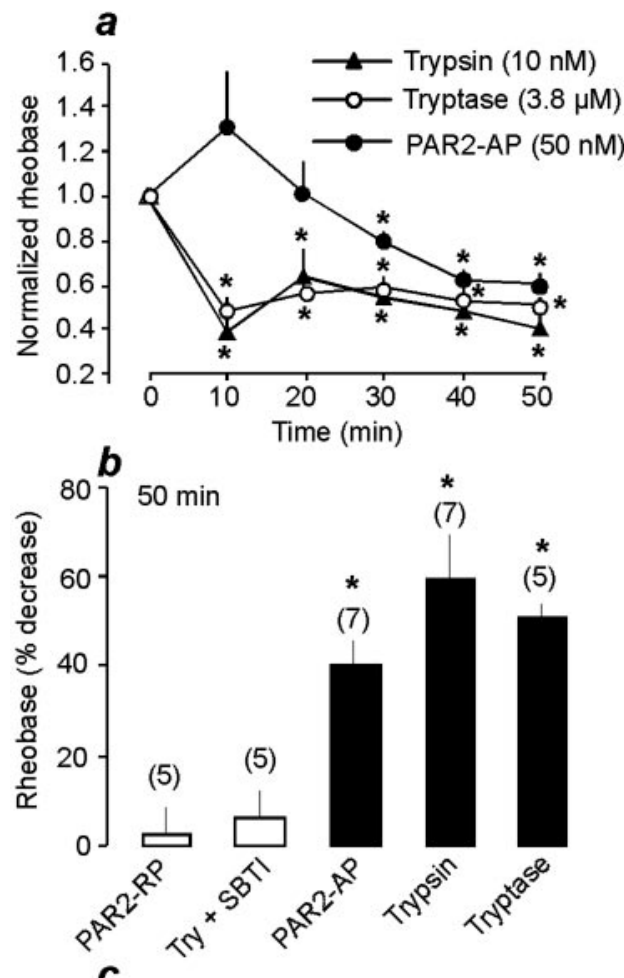

a $\quad 0$ min

- Capsaicin ( $500 \mathrm{nM}$ )

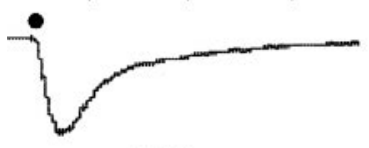

Basal
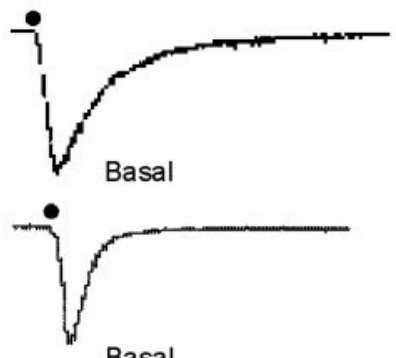

Basal
$30 \mathrm{~min}$
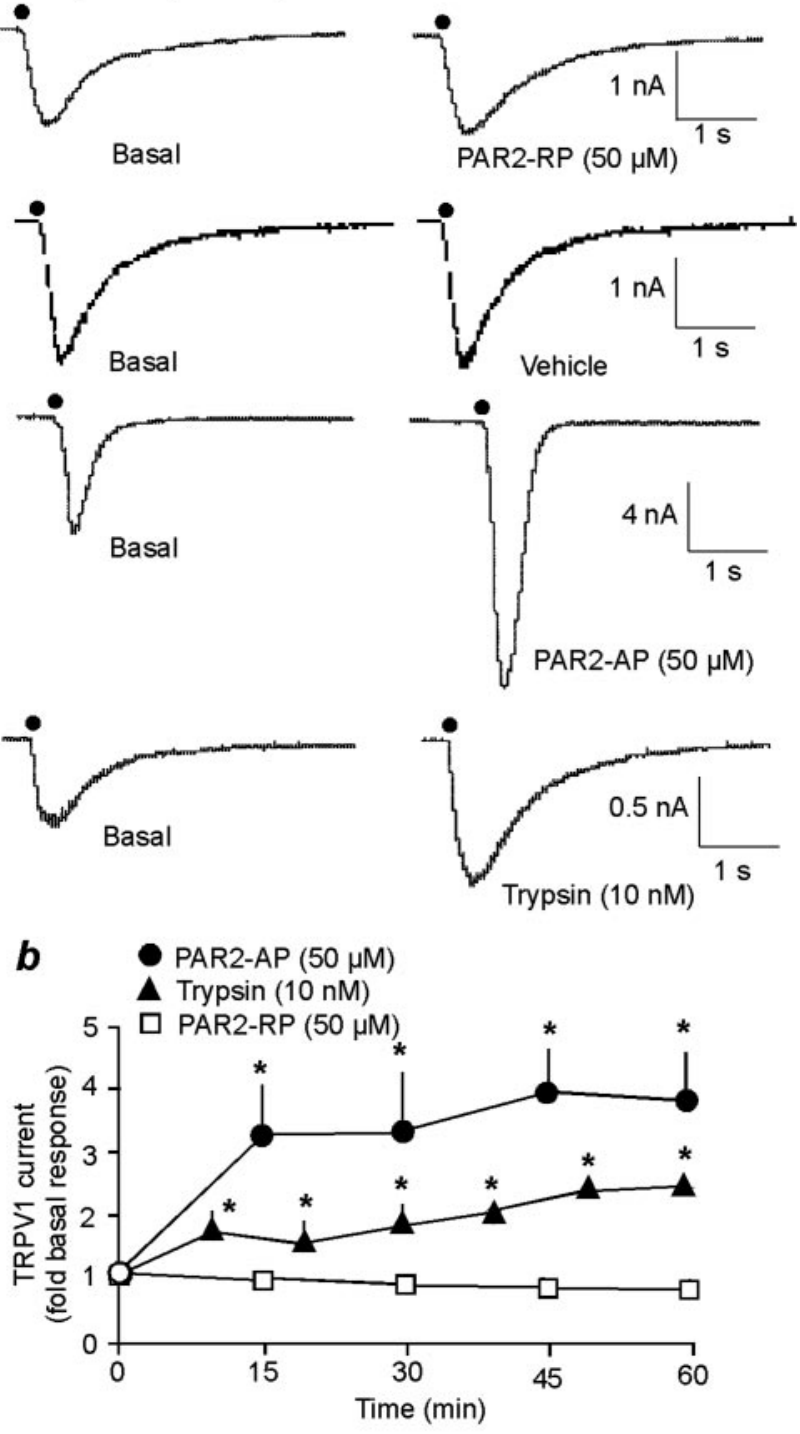

c

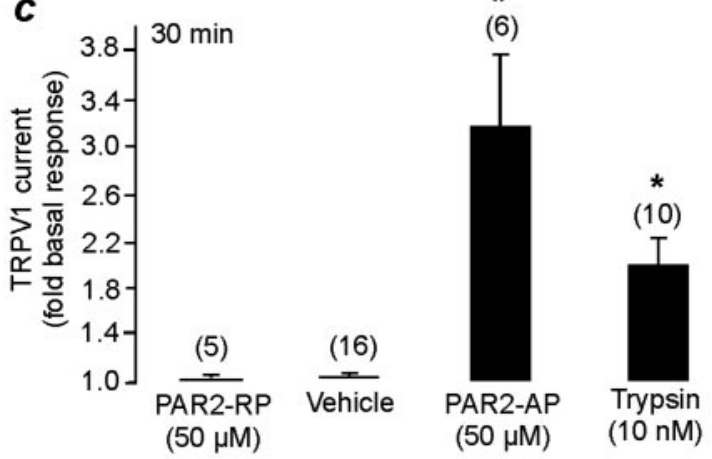

Figure 4. $P A R_{2}$ activation excites $D R G$ neurons in culture. Neurons were superfused for 3 min with $\mathrm{PAR}_{2}-\mathrm{AP}$ or $-\mathrm{RP}(50 \mu \mathrm{M})$ or trypsin or SBTl-treated trypsin $(10 \mathrm{~nm})$ or puffed with tryptase $(3.8 \mu \mathrm{m})$. The rheobase $(a, b)$ and membrane potential $(c, d)$ were measured at the indicated times. Trypsin and tryptase caused a sustained decrease in rheobase that was maintained for at least $50 \mathrm{~min}$. PAR 2 -AP caused a transient increase in rheobase at $10 \mathrm{~min}$ followed by a sustained decrease $(a)$. This effect was nonspecific because PAR $_{2}-\mathrm{RP}$ produced an identical transient increase (data not shown) without a sustained effect on rheobase $(b)$ or a transient decrease in membrane potential $(d)$. PAR 2 agonists caused a transient decrease in membrane potential $(c$, d). ${ }^{*} p<0.01$ compared with basal $(a, b)$ or PAR - RP and trypsin (Try) + SBTI $(c, d)$. Numbers in parentheses are numbers of neurons.
(7)

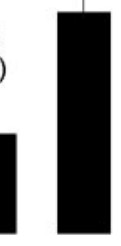

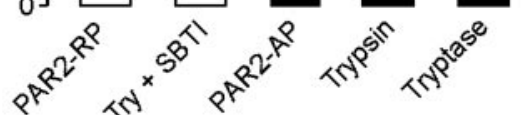

Figure 5. $P A R_{2}$ activation sensitizes TRPV1 currents. Neurons were superfused for 3 min with $\mathrm{PAR}_{2}-\mathrm{AP}$ or $-\mathrm{RP}(50 \mu \mathrm{m})$, trypsin $(10 \mathrm{~nm})$, or vehicle. They were challenged at the indicated times with capsaicin $(500 \mathrm{~nm})$, and currents were measured. $a$, Representative currents under basal conditions and at 30 min after activation of $\mathrm{PAR}_{2}$. PAR activation caused a marked and sustained increase in the capsaicin-induced current $(a, b)$, and the increase observed $30 \mathrm{~min}$ after activation is shown in $c .{ }^{*} p<0.01$ compared with basal $(b)$ or vehicle and $\operatorname{PAR}_{2}-\operatorname{RP}(c)$. Numbers in parentheses are numbers of neurons. 


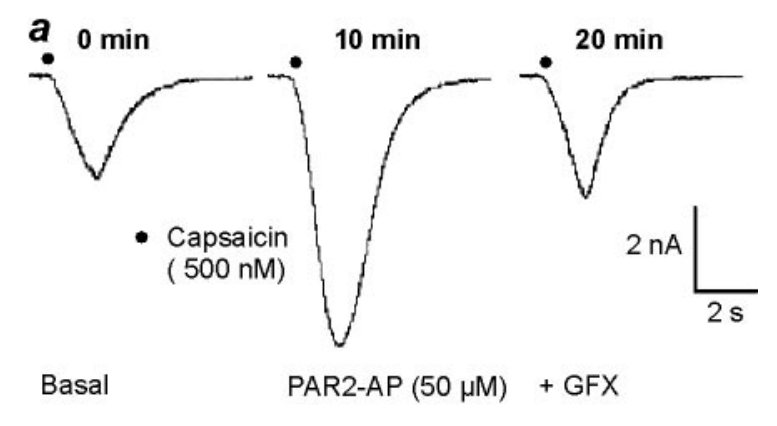

b
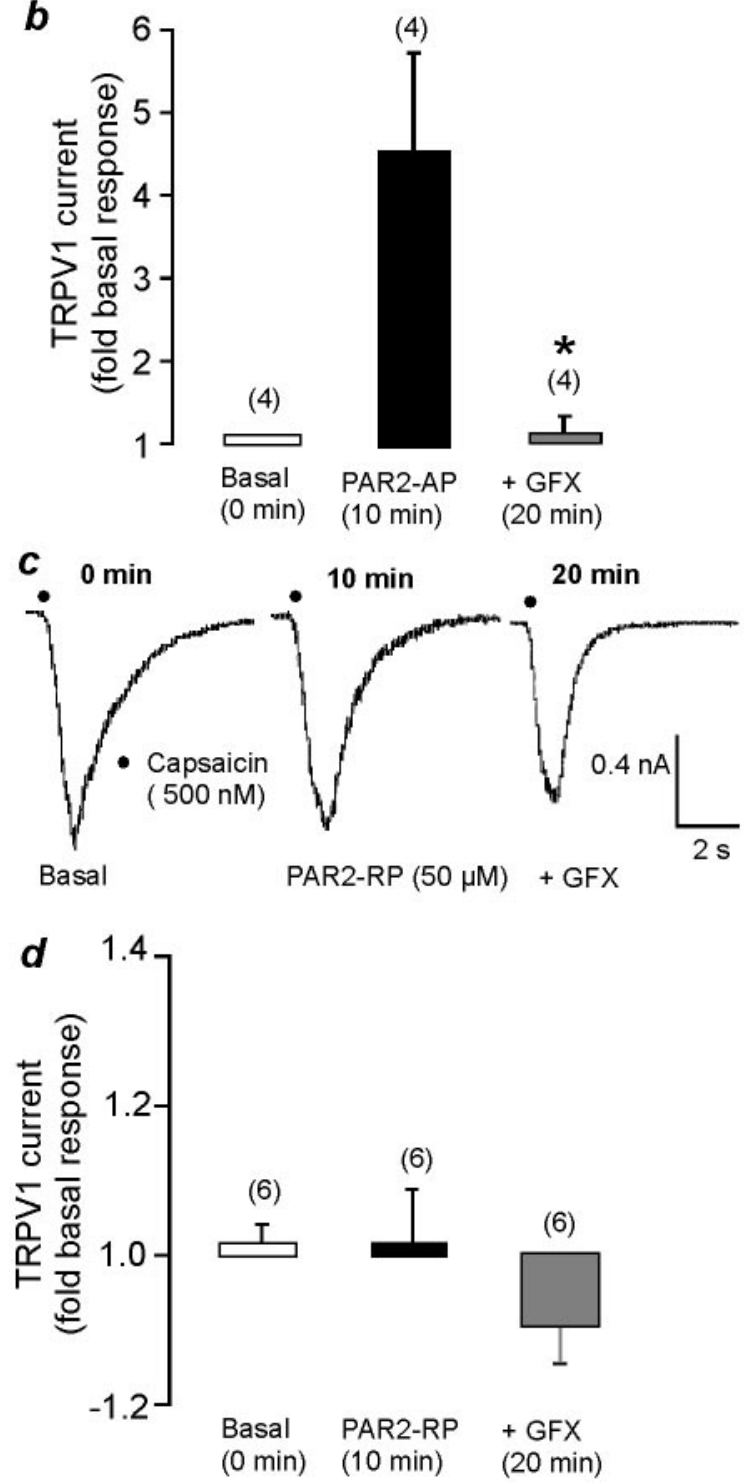

Figure 6. PAR activation sensitizes TRPV1 currents by a PKC-dependent mechanism. Neurons were superfused for 3 min with $\mathrm{PAR}_{2}-\mathrm{AP}$ or $-\mathrm{RP}(50 \mu \mathrm{m})$ and then challenged with capsaicin $(500 \mathrm{nM}) . \mathrm{PAR}_{2}$ activation caused a marked increase in the capsaicin current, and the increase was abolished by GFX (1 $\mu \mathrm{M})$. GFX had no effect in neurons treated with $\mathrm{PAR}_{2}$-RP. Representative traces are shown in $a$ and $c$, and pooled data are shown in $b$ and $d .{ }^{*} p<0.01$ compared with vehicle and $P A R_{2}-A P$. Numbers in parentheses are numbers of neurons.

HEK-TRPV1 cells, whereas $\mathrm{PAR}_{2}-\mathrm{RP}(100 \mu \mathrm{M})$ or vehicle had no effect. PMA (10 $\mu \mathrm{M}, 10 \mathrm{~min})$ also increased the phosphorylation of TRPV1, whereas vehicle (DMSO, 1:250) had no effect (Fig. 7). Thus, stimulation of $\mathrm{PAR}_{2}$ directly phosphorylates TRPV1.
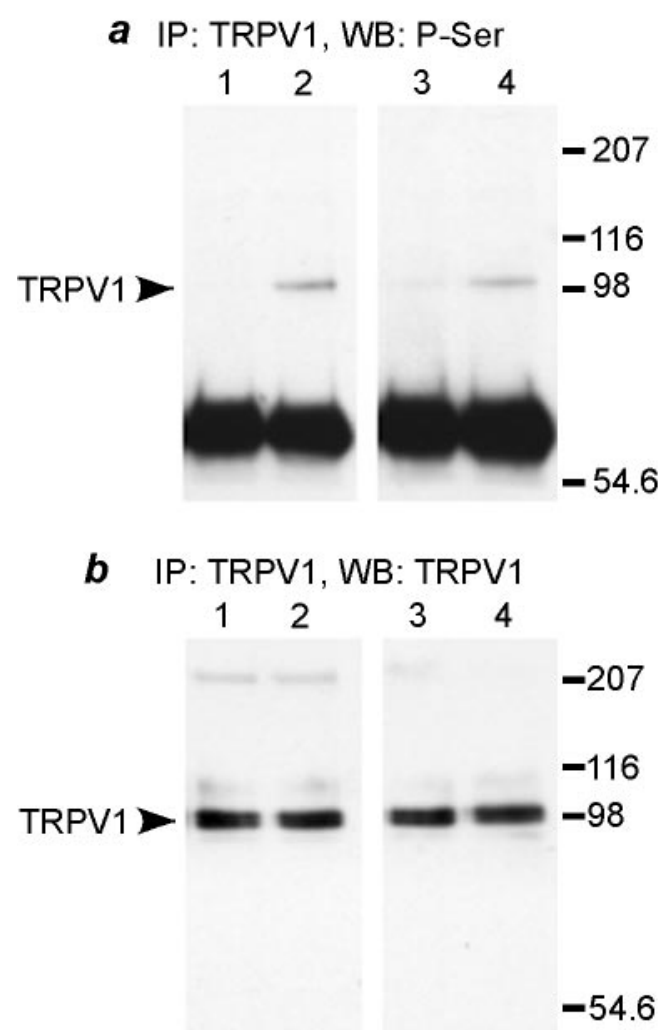

\section{Lane 1- PAR2-RP $(100 \mu \mathrm{M}, 10 \mathrm{~min})$ Lane 2 - PAR2-AP (100 $\mu \mathrm{M}, 10 \mathrm{~min})$ Lane 3 - DMSO (1:250, $10 \mathrm{~min})$ Lane 4 - PMA (10 $\mu \mathrm{M}, 10 \mathrm{~min})$}

Figure 7. Agonist of PAR ${ }_{2}$ induced phosphorylation of TRPV1. HEK-TRPV1 cells were exposed to PAR 2 -AP or -RP $(100 \mu \mathrm{M})$, PMA $(10 \mu \mathrm{M})$, or DMSO (1:250) for 10 min. TRPV1 was immunoprecipitated (IP), and Western blots (WB) were probed for phosphoserine (a). Blots were then stripped and reprobed to TRPV1 to ensure equal loading $(b)$. Activation of PAR 2 and PKC induced serine phosphorylation of TRPV1. Representative blots are shown.

$\mathrm{PAR}_{2}$ agonists induced thermal hyperalgesia by a mechanism that was mediated by TRPV1 and protein kinase $C$

The intraplantar injection of trypsin, tryptase, and $\mathrm{PAR}_{2}-\mathrm{AP}$, at doses that do not cause detectable inflammation of the paw, induces sustained thermal and mechanical hyperalgesia (Vergnolle et al., 2001). Because TRPV1 is an important mediator of thermal hyperalgesia and inflammatory pain (Caterina et al., 1997; Tominaga et al., 1998; Zygmunt et al., 1999; Caterina et al., 2000; Davis et al., 2000), we evaluated the role of TRPV1 in $\mathrm{PAR}_{2}$-induced thermal hyperalgesia using pharmacological and genetic approaches. Intraplantar injection of a subinflammatory dose of $\mathrm{PAR}_{2}-\mathrm{AP}$ in C57BL/6 mice ( $1 \mu \mathrm{g} /$ paw; Vergnolle et al., 2001), decreased the latency of paw withdrawal from a thermal stimulus for $30 \mathrm{~min}$ to at least $4 \mathrm{hr}$, indicative of sustained thermal hyperalgesia (Fig. 8a). Intraplantar $\mathrm{PAR}_{2}-\mathrm{RP}(1 \mu \mathrm{g} /$ paw) did not affect withdrawal latency. Pretreatment with the TRPV1 antagonist capsazepine (35 mg/kg, s.c.) markedly inhibited $\mathrm{PAR}_{2}$-induced hyperalgesia compared with animals treated with vehicle (Fig. $8 a)$. In TRPV1 ${ }^{+/+}$mice, intraplantar injection $\mathrm{PAR}_{2}-\mathrm{AP}$ but not $\mathrm{PAR}_{2}-\mathrm{RP}(1 \mu \mathrm{g} / \mathrm{paw})$ also caused a sustained decrease in latency of paw withdrawal (Fig. $8 b$ ). In contrast, $\mathrm{PAR}_{2}$-AP did not affect the latency of withdrawal in TRPV $1^{-1-}$ mice. Thus, TRPV1 is required for $\mathrm{PAR}_{2}$-induced thermal hyperalgesia.

To examine the capacity of $\mathrm{PAR}_{2}$-AP to sensitize TRPV1, we 
simultaneously administered doses of $\mathrm{PAR}_{2}-\mathrm{AP}$ and capsaicin that alone did not cause hyperalgesia. By administration of graded doses of $\mathrm{PAR}_{2}-\mathrm{AP}$ (1-500 ng/paw) to $\mathrm{C} 57 \mathrm{BL} / 6$ mice, we determined that $1 \mathrm{ng}$ $\mathrm{PAR}_{2}$-AP had no effect on thermal hyperalgesia (Fig. $8 c$ ). Capsaicin ( $1 \mu \mathrm{g} /$ paw) also did not cause thermal hyperalgesia (Fig. $8 d$ ). However, coinjection of $\mathrm{PAR}_{2}-\mathrm{AP}$ (1 $\mathrm{ng} / \mathrm{paw})$ and capsaicin $(1 \mu \mathrm{g} / \mathrm{paw}) \mathrm{de}$ creased the latency of paw withdrawal, suggesting that $\mathrm{PAR}_{2}$ sensitizes TRPV1 to capsaicin (Fig. $8 d$ ). Similarly, in TRPV $1^{+/+}$mice, coinjection of $\mathrm{PAR}_{2}-\mathrm{AP}$ $(1 \mathrm{ng} / \mathrm{paw})$ and capsaicin $(1 \mu \mathrm{g} / \mathrm{paw}) \mathrm{de}-$ creased the latency of paw withdrawal for $30 \mathrm{~min}$ to $2 \mathrm{hr}$ (Fig. $8 e$ ). In TRPV1 ${ }^{-1-}$ mice, coinjection of $\mathrm{PAR}_{2}$-AP and capsaicin had no effect of withdrawal (Fig. $8 e$ ). Thus, $\mathrm{PAR}_{2}$ sensitizes responses to capsaicin by a mechanism that depends on TRPV1.

To determine whether PKC mediates this sensitization, we injected GFX locally into the paw. In C57BL/6 mice treated with GFX vehicle, coinjection of $\mathrm{PAR}_{2}$-AP ( $1 \mathrm{ng} / \mathrm{paw})$ and capsaicin $(1 \mu \mathrm{g} / \mathrm{paw}) \mathrm{de}-$ creased the latency of paw withdrawal (Fig. 8e). Pretreatment with GFX (1 $\mu \mathrm{g} /$ paw) completely inhibited the synergic effect of capsaicin and $\mathrm{PAR}_{2}$-AP on decreasing the withdrawal latency at all times. After $3 \mathrm{hr}$, animals pretreated with GFX showed an increased nociceptive threshold. GFX injected alone did not affect the latency of paw withdrawal at $0-2 \mathrm{hr}$ but slightly decreased withdrawal latency at 3 and $4 \mathrm{hr}$. Thus, $\mathrm{PAR}_{2}$ activation sensitizes TRPV1 to induce thermal hyperalgesia by a mechanism that is dependent on PKC.

\section{$\mathrm{PAR}_{2}$ activation enhanced capsaicin-} stimulated release of SP and CGRP in the spinal cord

The intraplantar injection of $\mathrm{PAR}_{2}$ agonists causes thermal hyperalgesia in part by stimulating the release of neuropeptides from the central projections of DRG in the dorsal horn of the spinal cord (Vergnolle et al., 2001). To determine whether $\mathrm{PAR}_{2}$ activation sensitizes TRPV1-stimulated neuropeptide release from the central projections of DRG neurons, we measured secretion of SP and CGRP from superfused slices of the rat spinal cord. Superfusion with capsaicin $(0.5$ or 1 $\mu \mathrm{M})$ stimulated release of SP- and CGRP-LI from the spinal cord (Fig. 9a,b). Pretreatment with $\mathrm{PAR}_{2}$-AP (10 $\left.\mu \mathrm{M}, 20 \mathrm{~min}\right)$ enhanced capsaicin-stimulated release of SP-LI by $>2$-fold and CGRP-LI by $>1.6$-fold compared with vehicle, whereas $\mathrm{PAR}_{2}$-RP $\left(10 \mu \mathrm{M}, 20 \mathrm{~min}\right.$ ) was ineffective. Thus, activation of $\mathrm{PAR}_{2}$ sensitizes TRPV1-mediated release of neuropeptides from the central projections of DRG neurons in the dorsal horn of the spinal cord, where they mediate nociceptive transmission. 6-8 mice per group.
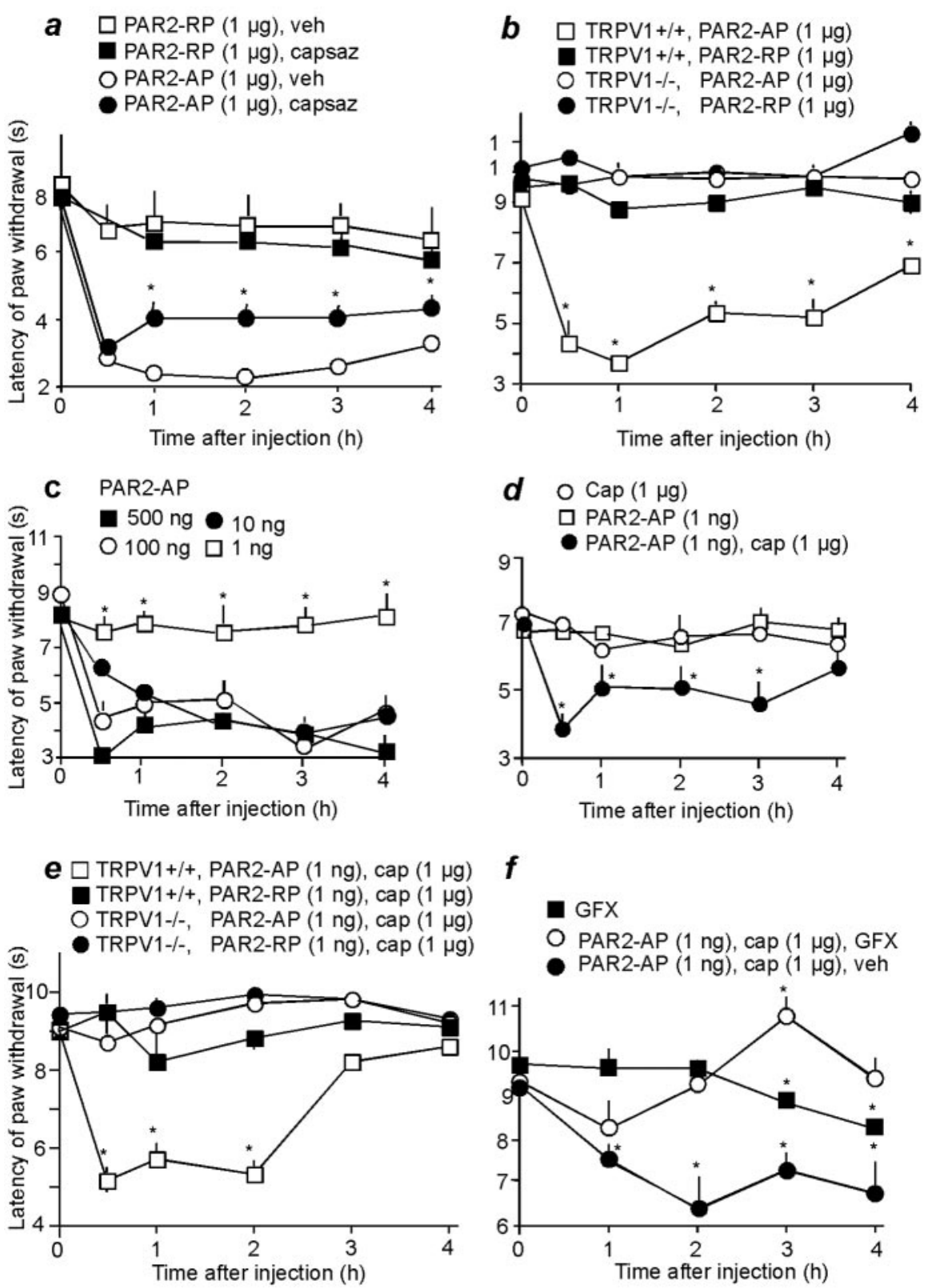

Figure 8. Mechanisms of $P A R_{2}$-induced thermal hyperalgesia in mice. $P A R_{2}-A P$ or $P A R_{2}-R P$ was administered by intraplantar injection, and latency of paw withdrawal was measured in C57BL/ 6 mice $(a, c, d, f)$ or TRPV1 ${ }^{+/+}$and TRPV1 ${ }^{-/-}$mice $(b, e) . a$, $P A R_{2}-A P$ decreased the latency of withdrawal, which was inhibited by systemic administration of capsazepine (capsaz; $35 \mathrm{mg} / \mathrm{kg}$, s.c.). $b$, PAR $_{2}-$ AP also decreased the latency of withdrawal in TRPV1 ${ }^{+/+}$mice but not TRPV1 ${ }^{-1-}$ mice. $c$, The effect of PAR $-A P$ on withdrawal latency was dose-related. $d$, Coinjection of $P_{2} R_{2}-A P$ and capsaicin (Cap) at doses that alone did not cause hyper-

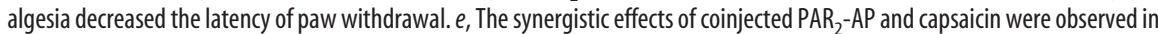
TRPV $^{+/+}$but not TRPV1 ${ }^{-1-}$ mice. $f$, Intraplantar injection of GFX $(1 \mu \mathrm{g} / \mathrm{paw})$ inhibited the synergistic effects of PAR $-A P$ and capsaicin. veh, Vehicle. ${ }^{*} p<0.05$ compared with basal withdrawal latency $(b, d-f)$ or PAR $-\mathrm{AP}_{2}$-induced hyperalgesia $(a, c) ; n=$

\section{Discussion}

$\mathrm{PAR}_{2}$ has been recently suggested to play a role in nociceptive signaling (Hoogerwerf et al., 2001; Kawabata et al., 2001a; Vergnolle et al., 2001; Coelho et al., 2002). However, the mechanism by which proteases that activate $\mathrm{PAR}_{2}$ induce hyperalgesia is unknown. From a combination of observations in transfected cell lines, cultured DRG, spinal cord slices, and intact animals, we conclude that $\mathrm{PAR}_{2}$ sensitizes TRPV1 through a PKC-dependent mechanism, and TRPV1 is required for $\mathrm{PAR}_{2}$-induced thermal hyperalgesia. 


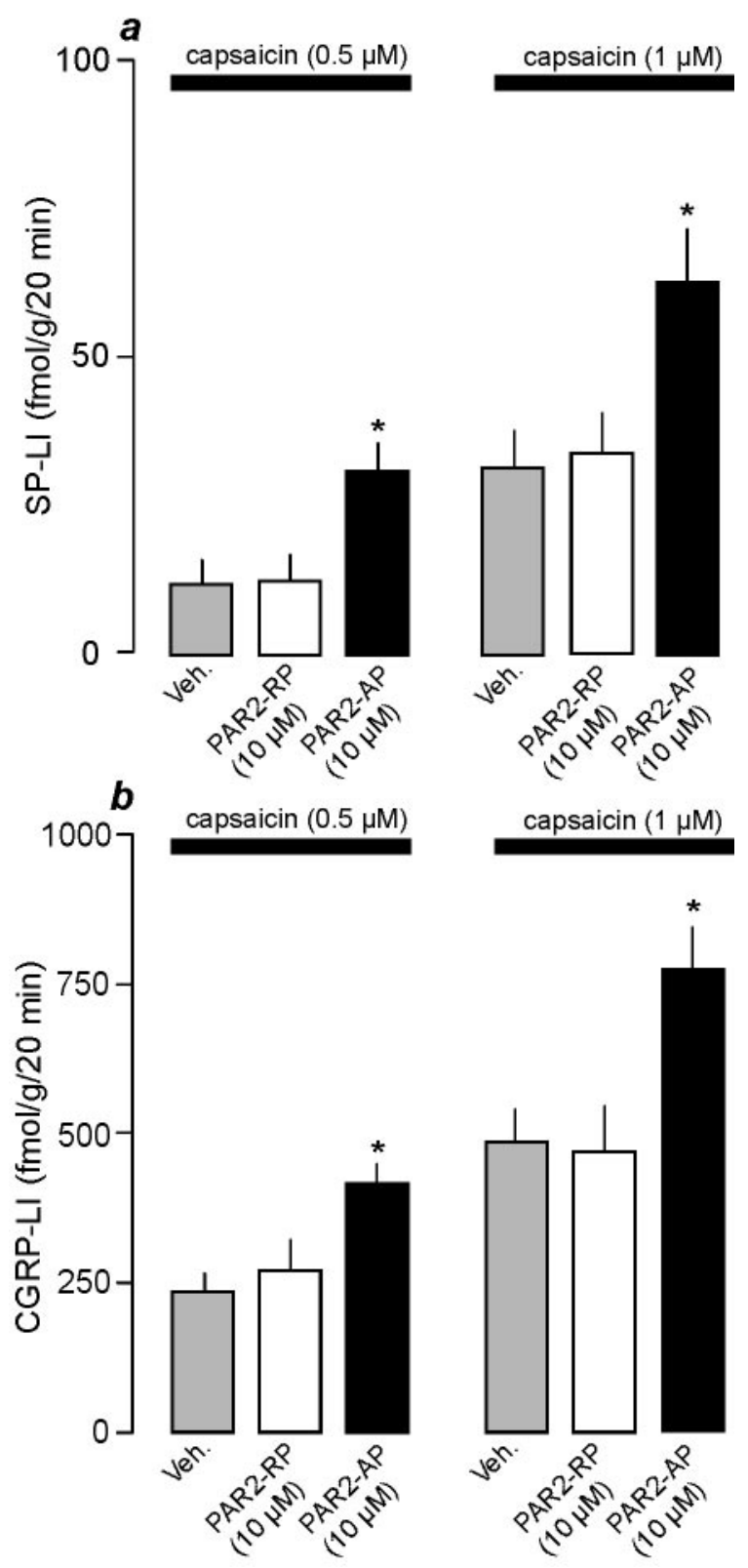

Figure 9. $\mathrm{PAR}_{2}$ activation sensitizes TRPV1-mediated release of SP $(a)$ and $\operatorname{GRP}(b)$. Slices of dorsal horn of the spinal cord were pretreated with vehicle (Veh.) or PAR ${ }_{2}-A P$ or $-\mathrm{RP}(10 \mu \mathrm{m})$ for 20 min and then challenged with capsaicin $(0.5$ or $1 \mu \mathrm{m})$. Pretreatment with $\mathrm{PAR}_{2}-\mathrm{AP}$ enhances capsaicin-stimulated release of SP-LI and GRP-LI. ${ }^{*} p<0.05$ compared with vehicle or $\mathrm{PAR}_{2}-\mathrm{RP} ; n=6-8$ rats.

\section{$\mathrm{PAR}_{2}$ sensitizes TRPV1 to cause thermal hyperalgesia}

Our conclusion that $\mathrm{PAR}_{2}$ sensitizes TRPV1 is based on several observations. First, in HEK-TRPV1 cells and DRG neurons, $\mathrm{PAR}_{2}$ agonists increased the magnitude of the $\mathrm{Ca}^{2+}$ response to capsaicin and the proportion of capsaicin-responsive neurons. Thus, activation of $\mathrm{PAR}_{2}$ both magnifies TRPV1 responses and recruits additional neurons that were previously unresponsive to capsaicin. Second, $\mathrm{PAR}_{2}$ agonists induced a sustained potentiation of TRPV1 currents in DRG neurons. Third, intraplantar injection of $\mathrm{PAR}_{2}-\mathrm{AP}$ induced a persistent thermal hyperalgesia that was mediated by TRPV1 because it was inhibited by antagonism or deletion of this channel. The finding that coinjection of nonhyperalgesic doses of $\mathrm{PAR}_{2}-\mathrm{AP}$ and capsaicin caused hyperalgesia that was also entirely dependent on TRPV1 confirms that
$\mathrm{PAR}_{2}$ sensitizes TRPV1 in vivo. Finally, superfusion of spinal cord slices with $\mathrm{PAR}_{2}$-AP potentiated TRPV1-mediated release of SP and CGRP. These neuropeptides derive from the central projections of DRG neurons in the spinal cord, where they mediate $\mathrm{PAR}_{2}$-induced hyperalgesia (Hoogerwerf et al., 2001; Kawabata et al., 2001a; Vergnolle et al., 2001; Coelho et al., 2002). In experiments with transfected cells, cultured neurons, spinal cord slices, and intact animals, we used a synthetic peptide and proteases to activate $\mathrm{PAR}_{2}$. $\mathrm{PAR}_{2}-\mathrm{AP}\left(\mathrm{SLIGRL}-\mathrm{NH}_{2}\right.$ ) selectively activates this receptor and does not activate other known $P A R s . P_{2}-R P$, which does not activate $\mathrm{PAR}_{2}$, did not sensitize TRPV1-induced $\mathrm{Ca}^{2+}$ signals or currents and had no effect on capsaicin-induced neuropeptide release or thermal hyperalgesia, confirming specificity. We have previously reported that the effects of trypsin and tryptase on DRG neurons are desensitized by $\mathrm{PAR}_{2}-\mathrm{AP}$, and their hyperalgesic actions are not detected in $\mathrm{PAR}_{2}$-deficient animals, suggesting that they induce hyperalgesia by activation of this receptor (Steinhoff et al., 2000; Vergnolle et al., 2001).

$\mathrm{PAR}_{1}$ is also coexpressed with CGRP in DRG neurons, and $\mathrm{PAR}_{1}$ agonists induce neurogenic inflammation (de Garavilla et al., 2001). Although $\mathrm{PAR}_{1}$ was coexpressed with TRPV1 in HEKTRPV1 cells and DRG neurons, $\mathrm{PAR}_{1}$-AP did not sensitize TRPV1 $\mathrm{Ca}^{2+}$ responses. This finding is consistent with the report that $\mathrm{PAR}_{1}$ activation induces thermal and mechanical analgesia rather than hyperalgesia (Asfaha et al., 2002). The mechanism of the differential effects of $\mathrm{PAR}_{1}$ and $\mathrm{PAR}_{2}$ agonists on TRPV1 agonists is unknown, although activation of divergent signaling pathways is a probable explanation. Although both $\mathrm{PAR}_{1}$ and $\mathrm{PAR}_{2}$ couple to PLC $\beta$ and similarly mobilized intracellular $\mathrm{Ca}^{2+}$ in HEK-TRPV1 and DRG neurons, $\mathrm{PAR}_{1}$ more prominently regulates adenylyl cyclase, and $\mathrm{PAR}_{1}$ and $\mathrm{PAR}_{2}$ regulate mitogenactivated protein kinases by different mechanisms (for review, see Ossovskaya and Bunnett, 2004). Further investigation is required to define the mechanism of the different effects of $\mathrm{PAR}_{1}$ and $\mathrm{PAR}_{2}$ on TRPV1 in neurons.

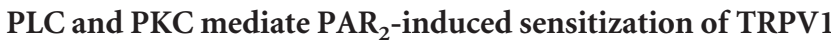

Inflammatory agents (e.g., bradykinin, ATP, $\mathrm{PGE}_{2}$, and NGF) can indirectly sensitize TRPV1 to cause hyperalgesia. It is important to understand the mechanisms of this sensitization because it may explain the hyperalgesic effects of diverse inflammatory mediators. Our observation that an inhibitor of PLC prevented $\mathrm{PAR}_{2}$-induced sensitization of TRPV1 is expected because $\mathrm{PAR}_{2}$ couples to PLC $\beta$ with subsequent formation of $\operatorname{InsP}_{3}$ and DAG, followed by mobilization of $\mathrm{Ca}^{2+}$ and activation of PKC. PLC $\beta$ can regulate TRPV1 by controlling the levels of its substrate, $\mathrm{PIP}_{2}$, which directly binds and inhibits TRPV1 (Chuang et al., 2001; Prescott and Julius, 2003). Thus, bradykinin and NGF, which activate PLC $\beta$, release TRPV1 from $\mathrm{PIP}_{2}$-mediated inhibition. $\mathrm{PAR}_{2}$ could similarly sensitize TRPV1 by reducing PIP $\mathrm{P}_{2}$ levels. However, PLC $\beta$ also regulates TRPV1 by DAG formation and subsequent activation of $\mathrm{PKC}$, which in turn phosphorylates and sensitizes TRPV1 (Tominaga et al., 2001; Vellani et al., 2001; Crandall et al., 2002; Prescott and Julius, 2003). Our observation that two distinct inhibitors of PKC prevented $\mathrm{PAR}_{2}$-induced sensitization of TRPV1 suggests that the activation of PKC plays a major role in $\mathrm{PAR}_{2}$-induced sensitization of TRPV1.

We do not know which isozyme of PKC is responsible for $\mathrm{PAR}_{2}$-induced sensitization of TRPV1. There are at least $11 \mathrm{PKC}$ isozymes, some of which make major contributions to nociception. An inhibitor of the $\alpha, \beta_{1}, \beta_{2}$, and $\gamma$ PKC isozymes (Gö6976) prevented sensitization in HEK cells and neurons, suggesting an involvement of at least these isozymes, which have been impli- 
cated in nociception. PKC $\alpha$, which is coexpressed with SP and CGRP in DRG neurons (Cesare et al., 1999; Olah et al., 2002), mediates upregulation of CGRP expression during chronic treatment with opioids (Belanger et al., 2002) and may enhance inflammatory pain (Olah et al., 2002). PKC $\beta$ participates in inflammatory thermal hyperalgesia (Igwe and Chronwall, 2001) and in persistent pain (Miletic et al., 2000). PKC $\gamma$ contributes to persistent neuropathic pain but not acute pain (Malmberg et al., 1997). Although Gö6976 does not inhibit PKC $\epsilon$, this isoform plays a major role in pain transmission (Khasar et al., 1999) and the regulation of TRPV1 (Cesare et al., 1999). Thus, we cannot exclude the contribution of PKC $\epsilon$ to PAR2-induced sensitization of TRPV1. Moreover, because $\mathrm{PAR}_{2}$-dependent sensitization of TRPV1 is remarkably sustained, different isoforms of PKC may contribute to sensitization at different times, as reported for the contribution of PKC $\epsilon$ to mechanical hyperalgesia (Aley et al., 2000).

Additional mechanisms may also regulate TRPV1. For example, $\mathrm{PGE}_{2}$ sensitizes TRPV1 responses by a protein kinase A-mediated mechanism (Hu et al., 2002; Rathee et al., 2002; Mohapatra and Nau, 2003), whereas bradykinin transactivates TRPV1 through the generation of 12-lipoxygenase metabolites of arachidonic acid (Shin et al., 2002). $\mathrm{PAR}_{2}$ stimulation induces release of arachidonic acid and $\mathrm{PGE}_{2}$ from epithelial cells (Kong et al., 1997), and these mechanisms could also contribute to $\mathrm{PAR}_{2}$-induced sensitization of TRPV1. However, inhibitors of cyclooxygenase (indomethacin and ibuprofen) and lipoxygenase (5,8,11,14-eicosatetraynoic acid) do not affect $\mathrm{PAR}_{2}$-mediated sensitization of TRPV1 $\mathrm{Ca}^{2+}$ signaling in HEK cells (N. W. Bunnett, unpublished observation).

\section{$\mathrm{PAR}_{2}$ activation induces phosphorylation of TRPV1}

TRPV1 is regulated in part by its phosphorylation state. Dephosphorylation of TRPV1 by calcineurin, a $\mathrm{Ca}^{2+}$ - and calmodulindependent kinase, can desensitize capsaicin responsiveness (Docherty et al., 1996), whereas phosphorylation may sensitize TRPV1 (Numazaki et al., 2002). TRPV1 contains 16 Ser and Thr residues that are potential sites for PKC-dependent phosphorylation. Phorbol esters and ATP, which potentiate the TRPV1 current and reduce the temperature threshold for activation, induce phosphorylation of TRPV1 (Numazaki et al., 2002). This process appears to increase the probability that TRPV1 will open in response to agonists (Vellani et al., 2001). Our results show that $\mathrm{PAR}_{2}$ activation induces phosphorylation of TRPV1. Thus, it is likely that $\mathrm{PAR}_{2}$ agonists similarly induce phosphorylation of TRPV1 by a PKC-dependent mechanism to regulate channel gating.

\section{$\mathrm{PAR}_{2}$ regulates the excitability of nociceptive neurons}

We found that $\mathrm{PAR}_{2}$ activation by brief exposure to $\mathrm{PAR}_{2}-\mathrm{AP}$, trypsin, or tryptase caused a sustained decrease in the rheobase of nociceptive neurons, indicative of an increase in their electrical excitability. In support of our results, $\mathrm{PAR}_{2}$ activation of S-type neurons in the submucosal plexus also causes a sustained decrease in rheobase and an increase in input resistance (Reed et al., 2003). The mechanism of the increased excitability of DRG neurons remains to be determined, although alterations in activity of ion channels other than TRPV1 may contribute. DRG neurons express multiple voltage-gated channels for $\mathrm{Na}^{+}, \mathrm{Ca}^{2+}$, and $\mathrm{K}^{+}$ ions that are regulated directly by G-proteins or by second messenger kinases. For example, PKC regulates a tetrodotoxinresistant $\mathrm{Na}^{+}$channel in nociceptive neurons (Gold et al., 1998) and $\mathrm{PAR}_{2}$ may regulate the activity of this channel and thereby enhance sensitivity. Alterations in membrane potential can also affect TRPV1 activity. The TRPV1 current in DRG neurons increases on membrane depolarization, suggesting that voltage serves as an intrinsic coactivator of this channel (Ahern and Premkumar, 2002). Thus, $\mathrm{PAR}_{2}$ activation increases the excitability of neurons by varying mechanisms and may sensitize their responses to agonists of TRPV1 or other agents to result in exacerbated inflammation and hyperalgesia.

In summary, we have identified a novel mechanism by which proteases cleave $\mathrm{PAR}_{2}$ on sensory nerves and sensitize TRPV1 to induce sustained thermal hyperalgesia. Sensitization requires activation of PLC and PKC and is probably mediated by direct phosphorylation of TRPV1 to enhance channel gating. $\mathrm{PAR}_{2}$ induced sensitization of TRPV1 causes enhanced release of neuropeptides in the spinal cord and exacerbated thermal pain. Proteases that activate $\mathrm{PAR}_{2}$, such as mast cell tryptase, coagulation factors VIIa and Xa, and extrapancreatic trypsins, are released and generated during injury and inflammation, which suggests that this mechanism plays an important role in these states. Although antagonists of $\mathrm{PAR}_{2}$ are not currently available, our results suggest that inhibitors or antagonists of proteases, TRPV1, and PKC may offer new therapies for treatment of sustained inflammatory pain.

\section{References}

Abdulla FA, Smith PA (1997) Nociceptin inhibits T-type $\mathrm{Ca}^{2+}$ channel current in rat sensory neurons by a G-protein-independent mechanism. J Neurosci 17:8721-8728.

Ahern GP, Premkumar LS (2002) Voltage-dependent priming of rat vanilloid receptor: effects of agonist and protein kinase $\mathrm{C}$ activation. J Physiol (Lond) 545:441-451.

Aley KO, Messing RO, Mochly-Rosen D, Levine JD (2000) Chronic hypersensitivity for inflammatory nociceptor sensitization mediated by the epsilon isozyme of protein kinase C. J Neurosci 20:4680-4685.

Alm AK, Gagnemo-Persson R, Sorsa T, Sundelin J (2000) Extrapancreatic trypsin-2 cleaves proteinase-activated receptor-2. Biochem Biophys Res Commun 275:77-83.

Asfaha S, Brussee V, Chapman K, Zochodne DW, Vergnolle N (2002) Proteinase-activated receptor-1 agonists attenuate nociception in response to noxious stimuli. Br J Pharmacol 135:1101-1106.

Belanger S, Ma W, Chabot JG, Quirion R (2002) Expression of calcitonin gene-related peptide, substance $\mathrm{P}$ and protein kinase $\mathrm{C}$ in cultured dorsal root ganglion neurons following chronic exposure to mu, delta and kappa opiates. Neuroscience 115:441-453.

Bohm SK, Khitin LM, Grady EF, Aponte G, Payan DG, Bunnett NW (1996) Mechanisms of desensitization and resensitization of proteinase-activated receptor-2. J Biol Chem 271:22003-22016.

Camerer E, Huang W, Coughlin SR (2000) Tissue factor- and factor $\mathrm{X}$-dependent activation of protease-activated receptor 2 by factor VIIa. Proc Natl Acad Sci USA 97:5255-5260.

Caterina MJ, Schumacher MA, Tominaga M, Rosen TA, Levine JD, Julius D (1997) The capsaicin receptor: a heat-activated ion channel in the pain pathway. Nature 389:816-824.

Caterina MJ, Leffler A, Malmberg AB, Martin WJ, Trafton J, Petersen-Zeitz KR, Koltzenburg M, Basbaum AI, Julius D (2000) Impaired nociception and pain sensation in mice lacking the capsaicin receptor. Science 288:306-313.

Cenac N, Coelho AM, Nguyen C, Compton S, Andrade-Gordon P, MacNaughton WK, Wallace JL, Hollenberg MD, Bunnett NW, Garcia-Villar R, Bueno L, Vergnolle N (2002) Induction of intestinal inflammation in mouse by activation of proteinase-activated receptor-2. Am J Pathol 161:1903-1915.

Cenac N, Garcia-Villar R, Ferrier L, Larauche M, Vergnolle N, Bunnett NW, Coelho AM, Fioramonti J, Bueno L (2003) Proteinase-activated receptor-2-induced colonic inflammation in mice: possible involvement of afferent neurons, nitric oxide, and paracellular permeability. J Immunol 170:4296-4300.

Cesare P, Moriondo A, Vellani V, McNaughton PA (1999) Ion channels gated by heat. Proc Natl Acad Sci USA 96:7658-7663. 
Chan CL, Facer P, Davis JB, Smith GD, Egerton J, Bountra C, Williams NS, Anand P (2003) Sensory fibres expressing capsaicin receptor TRPV1 in patients with rectal hypersensitivity and faecal urgency. Lancet 361:385-391.

Chuang HH, Prescott ED, Kong H, Shields S, Jordt SE, Basbaum AI, Chao MV, Julius D (2001) Bradykinin and nerve growth factor release the capsaicin receptor from PtdIns(4,5)P2-mediated inhibition. Nature 411:957-962.

Coelho AM, Vergnolle N, Guiard B, Fioramonti J, Bueno L (2002) Proteinases and proteinase-activated receptor 2: a possible role to promote visceral hyperalgesia in rats. Gastroenterology 122:1035-1047.

Corvera CU, Dery O, McConalogue K, Bohm SK, Khitin LM, Caughey GH, Payan DG, Bunnett NW (1997) Mast cell tryptase regulates rat colonic myocytes through proteinase- activated receptor 2. J Clin Invest 100:1383-1393.

Cottrell G, Amadesi S, Grady EF, Bunnett NW (2004) Trypsin IV: a novel agonist of protease-activated receptors 2 and 4. J Biol Chem 279:1353213539.

Crandall M, Kwash J, Yu W, White G (2002) Activation of protein kinase C sensitizes human VR1 to capsaicin and to moderate decreases in $\mathrm{pH}$ at physiological temperatures in Xenopus oocytes. Pain 98:109-117.

Davis JB, Gray J, Gunthorpe MJ, Hatcher JP, Davey PT, Overend P, Harries MH, Latcham J, Clapham C, Atkinson K, Hughes SA, Rance K, Grau E, Harper AJ, Pugh PL, Rogers DC, Bingham S, Randall A, Sheardown SA (2000) Vanilloid receptor-1 is essential for inflammatory thermal hyperalgesia. Nature 405:183-187.

de Garavilla L, Vergnolle N, Young SH, Ennes H, Steinhoff M, Ossovskaya VS, D’Andrea MR, Mayer EA, Wallace JL, Hollenberg MD, Andrade-Gordon P, Bunnett NW (2001) Agonists of proteinase-activated receptor 1 induce plasma extravasation by a neurogenic mechanism. Br J Pharmacol 133:975-987.

Docherty RJ, Yeats JC, Bevan S, Boddeke HW (1996) Inhibition of calcineurin inhibits the desensitization of capsaicin-evoked currents in cultured dorsal root ganglion neurones from adult rats. Pflügers Arch 431:828-837.

Gao C, Liu S, Hu HZ, Gao N, Kim GY, Xia Y, Wood JD (2002) Serine proteases excite myenteric neurons through protease-activated receptors in guinea pig small intestine. Gastroenterology 123:1554-1564.

Gold MS, Levine JD, Correa AM (1998) Modulation of TTX-R INa by PKC and PKA and their role in PGE2-induced sensitization of rat sensory neurons in vitro. J Neurosci 18:10345-10355.

Hayes P, Meadows HJ, Gunthorpe MJ, Harries MH, Duckworth DM, Cairns W, Harrison DC, Clarke CE, Ellington K, Prinjha RK, Barton AJ, Medhurst AD, Smith GD, Topp S, Murdock P, Sanger GJ, Terrett J, Jenkins O, Benham CD, Randall AD, Gloger IS, Davis JB (2000) Cloning and functional expression of a human orthologue of rat vanilloid receptor-1. Pain 88:205-215.

Hoogerwerf WA, Zou L, Shenoy M, Sun D, Micci MA, Lee-Hellmich H, Xiao SY, Winston JH, Pasricha PJ (2001) The proteinase-activated receptor 2 is involved in nociception. J Neurosci 21:9036-9042.

Hu HJ, Bhave G, Gereau RW (2002) Prostaglandin and protein kinase A-dependent modulation of vanilloid receptor function by metabotropic glutamate receptor 5: potential mechanism for thermal hyperalgesia. J Neurosci 22:7444-7452.

Igwe OJ, Chronwall BM (2001) Hyperalgesia induced by peripheral inflammation is mediated by protein kinase $\mathrm{C}$ betaII isozyme in the rat spinal cord. Neuroscience 104:875-890.

Ishihara H, Connolly AJ, Zeng D, Kahn ML, Zheng YW, Timmons C, Tram T, Coughlin SR (1997) Protease-activated receptor 3 is a second thrombin receptor in humans. Nature 386:502-506.

Kahn ML, Zheng YW, Huang W, Bigornia V, Zeng D, Moff S, Farese Jr RV, Tam C, Coughlin SR (1998) A dual thrombin receptor system for platelet activation. Nature 394:690-694.

Kawabata A, Kawao N, Kuroda R, Tanaka A, Itoh H, Nishikawa H (2001a) Peripheral PAR-2 triggers thermal hyperalgesia and nociceptive responses in rats. NeuroReport 12:715-719.

Kawabata A, Kinoshita M, Nishikawa H, Kuroda R, Nishida M, Araki H, Arizono N, Oda Y, Kakehi K (2001b) The protease-activated receptor-2 agonist induces gastric mucus secretion and mucosal cytoprotection. J Clin Invest 107:1443-1450.

Kawabata A, Kinoshita M, Kuroda R, Kakehi K (2002) Capsazepine partially inhibits neurally mediated gastric mucus secretion following activation of protease-activated receptor 2. Clin Exp Pharmacol Physiol 29:360-361.

Kawao N, Shimada C, Itoh H, Kuroda R, Kawabata A (2002) Capsazepine inhibits thermal hyperalgesia but not nociception triggered by proteaseactivated receptor-2 in rats. Jpn J Pharmacol 89:184-187.

Khasar SG, Lin YH, Martin A, Dadgar J, McMahon T, Wang D, Hundle B, Aley KO, Isenberg W, McCarter G, Green PG, Hodge CW, Levine JD, Messing RO (1999) A novel nociceptor signaling pathway revealed in protein kinase C epsilon mutant mice. Neuron 24:253-260.

Kirkup AJ, Jiang W, Bunnett NW, Grundy D (2004) Stimulation of the proteinase-activated receptor 2 excites jejunal afferent nerves in anaesthetized rats. Physiol Rev 84:579-621.

Kong W, McConalogue K, Khitin LM, Hollenberg MD, Payan DG, Bohm SK, Bunnett NW (1997) Luminal trypsin may regulate enterocytes through proteinase-activated receptor 2. Proc Natl Acad Sci USA 94:8884-8889.

Linden DR, Manning BP, Bunnett NW, Mawe GM (2001) Agonists of proteinase-activated receptor 2 excite guinea pig ileal myenteric neurons. Eur J Pharmacol 431:311-314.

Malmberg AB, Chen C, Tonegawa S, Basbaum AI (1997) Preserved acute pain and reduced neuropathic pain in mice lacking PKCgamma. Science 278:279-283.

Miletic V, Bowen KK, Miletic G (2000) Loose ligation of the rat sciatic nerve is accompanied by changes in the subcellular content of protein kinase $\mathrm{C}$ beta II and gamma in the spinal dorsal horn. Neurosci Lett 288:199-202.

Mohapatra DP, Nau C (2003) Desensitization of capsaicin-activated currents in the vanilloid receptor TRPV1 is decreased by the cyclic AMPdependent protein kinase pathway. J Biol Chem 278:50080-50090.

Molino M, Barnathan ES, Numerof R, Clark J, Dreyer M, Cumashi A, Hoxie JA, Schechter N, Woolkalis M, Brass LF (1997) Interactions of mast cell tryptase with thrombin receptors and PAR-2. J Biol Chem 272:4043-4049.

Nicol GD, Cui M (1994) Enhancement by prostaglandin E2 of bradykinin activation of embryonic rat sensory neurones. J Physiol (Lond) 480:485-492.

Numazaki M, Tominaga T, Toyooka H, Tominaga M (2002) Direct phosphorylation of capsaicin receptor VR1 by protein kinase Cepsilon and identification of two target serine residues. J Biol Chem 277:13375-13378.

Nystedt S, Emilsson K, Wahlestedt C, Sundelin J (1994) Molecular cloning of a potential proteinase activated receptor. Proc Natl Acad Sci USA 91:9208-9212.

Olah Z, Karai L, Iadarola MJ (2002) Protein kinase C(alpha) is required for vanilloid receptor 1 activation: evidence for multiple signaling pathways. J Biol Chem 277:35752-35759.

Ossovskaya VS, Bunnett NW (2003) Protease-activated receptors: contribution to physiology and disease. J Physiol (Lond) 552:589-601.

Premkumar LS, Ahern GP (2000) Induction of vanilloid receptor channel activity by protein kinase C. Nature 408:985-990.

Prescott ED, Julius D (2003) A modular PIP2 binding site as a determinant of capsaicin receptor sensitivity. Science 300:1284-1288.

Rathee PK, Distler C, Obreja O, Neuhuber W, Wang GK, Wang SY, Nau C, Kress M (2002) PKA/AKAP/VR-1 module: a common link of Gsmediated signaling to thermal hyperalgesia. J Neurosci 22:4740-4745.

Reed DE, Barajas-Lopez C, Cottrell G, Velazquez-Rocha S, Dery O, Grady EF, Bunnett NW, Vanner SJ (2003) Mast cell tryptase and proteinaseactivated receptor 2 induce hyperexcitability of guinea-pig submucosal neurons. J Physiol (Lond) 547:531-542.

Ricciardolo FL, Steinhoff M, Amadesi S, Guerrini R, Tognetto M, Trevisani M, Creminon C, Bertrand C, Bunnett NW, Fabbri LM, Salvadori S, Geppetti P (2000) Presence and bronchomotor activity of proteaseactivated receptor-2 in guinea pig airways. Am J Respir Crit Care Med 161:1672-1680.

Sambrano GR, Huang W, Faruqi T, Mahrus S, Craik C, Coughlin SR (2000) Cathepsin $\mathrm{G}$ activates protease-activated receptor- 4 in human platelets. J Biol Chem 275:6819-6823.

Sawada K, Nishibori M, Nakaya N, Wang Z, Saeki K (2000) Purification and characterization of a trypsin-like serine proteinase from rat brain slices that degrades laminin and type IV collagen and stimulates proteaseactivated receptor-2. J Neurochem 74:1731-1738.

Shin J, Cho H, Hwang SW, Jung J, Shin CY, Lee SY, Kim SH, Lee MG, Choi YH, Kim J, Haber NA, Reichling DB, Khasar S, Levine JD, Oh U (2002) Bradykinin-12-lipoxygenase-VR1 signaling pathway for inflammatory hyperalgesia. Proc Natl Acad Sci USA 99:10150-10155. 
Shu X, Mendell LM (1999) Nerve growth factor acutely sensitizes the response of adult rat sensory neurons to capsaicin. Neurosci Lett 274:159-162.

Steinhoff M, Vergnolle N, Young SH, Tognetto M, Amadesi S, Ennes HS, Trevisani M, Hollenberg MD, Wallace JL, Caughey GH, Mitchell SE, Williams LM, Geppetti P, Mayer EA, Bunnett NW (2000) Agonists of proteinase-activated receptor 2 induce inflammation by a neurogenic mechanism. Nat Med 6:151-158.

Tominaga M, Caterina MJ, Malmberg AB, Rosen TA, Gilbert H, Skinner K, Raumann BE, Basbaum AI, Julius D (1998) The cloned capsaicin receptor integrates multiple pain-producing stimuli. Neuron 21:531-543.

Tominaga M, Wada M, Masu M (2001) Potentiation of capsaicin receptor activity by metabotropic ATP receptors as a possible mechanism for ATPevoked pain and hyperalgesia. Proc Natl Acad Sci USA 98:6951-6956.

Trevisani M, Smart D, Gunthorpe MJ, Tognetto M, Barbieri M, Campi B, Amadesi S, Gray J, Jerman JC, Brough SJ, Owen D, Smith GD, Randall AD, Harrison S, Bianchi A, Davis JB, Geppetti P (2002) Ethanol elicits and potentiates nociceptor responses via the vanilloid receptor-1. Nat Neurosci 5:546-551.

Vellani V, Mapplebeck S, Moriondo A, Davis JB, McNaughton PA (2001) Protein kinase $\mathrm{C}$ activation potentiates gating of the vanilloid receptor VR1 by capsaicin, protons, heat and anandamide. J Physiol (Lond) 534:813-825.

Vergnolle N, Bunnett NW, Sharkey KA, Brussee V, Compton SJ, Grady EF, Cirino G, Gerard N, Basbaum AI, Andrade-Gordon P, Hollenberg MD, Wallace JL (2001) Proteinase-activated receptor-2 and hyperalgesia: a novel pain pathway. Nat Med 7:821-826.

Vu TK, Hung DT, Wheaton VI, Coughlin SR (1991) Molecular cloning of a functional thrombin receptor reveals a novel proteolytic mechanism of receptor activation. Cell 64:1057-1068.

Zygmunt PM, Petersson J, Andersson DA, Chuang H, Sorgard M, Di Marzo V, Julius D, Hogestatt ED (1999) Vanilloid receptors on sensory nerves mediate the vasodilator action of anandamide. Nature 400:452-457. 